\title{
Role of ACE2 Receptor and the landscape of treatment options from Convalescent plasma therapy to the drug repurposing in COVID-19
}

Pravindra Kumar, ${ }^{1, *}$ Ashok Kumar Sah, ${ }^{2, *}$ Greesham Tripathi, ${ }^{3, *}$ Anjali Kashyap, ${ }^{4}$ Avantika Tripathi, ${ }^{3,}$ Rashmi Rao, ${ }^{1}$ Prabhu C Mishra, ${ }^{3}$ Koustav Mallick, ${ }^{5}$ Amjad Husain, ${ }^{6}$ Manoj Kumar Kashyap, ${ }^{1,3,+}$

${ }^{1}$ School of Life and Allied Health Sciences, The Glocal University, Saharanpur (UP), INDIA, ${ }^{2}$ Department of Laboratory Technology, \& ${ }^{3}$ Amity Stem Cell Institute, Amity Medical School, Amity University Haryana, Panchgaon, Manesar (Gurugram), Haryana, INDIA, and 4 Department of Biotechnology, Thapar Institute of Engineering \& Technology, Patiala (Punjab), India, ${ }^{5}$ National Liver Disease Biobank, Institute of Liver and Biliary Sciences, New Delhi, India, ${ }^{6}$ Centre for Science \& Society, Indian Institute of Science Education and Research, Bhopal, India

Running title: Repurposing in COVID-19 pandemic

Conflict of Interest: Authors declare no potential conflicts of interest.

*Authors contributed equally in this study.

Address for Correspondence:

'Manoj K Kashyap, Amity Stem Cell Institute, Amity Medical School, Amity University Haryana, Panchgaon (Manesar), Gurugram (HR)-122413, INDIA

E-mail: mkkashyap@ggn.amity.edu 


\section{ABSTRACT}

Since the first case reports in Wuhan, China, SARS-CoV-2 virus took lives of $>6,85,000$ people all around the world. This single stranded RNA virus used Angiotensin converting enzyme 2 (ACE2) as a receptor for entry into the host cell. Overexpression of ACE2 is observed in hypertensive, diabetic and heart patients that make them prone to COVID-19 infection. All around the world, mitigations strategies were opted by the governments to minimize transmission of COVID-19 via the implementation of social distancing norms, wearing the facemasks, and spreading awareness using digital platforms. The lack of an approved drug treatment regimen, and non-availability of a vaccine, collectively posed a challenge for mankind to fight against SARS-CoV-2 pandemic. In this scenario, repurposing of existing drugs and old treatment options like convalescent plasma therapy can be the potential alternatives to treat the disease. The Drug repurposing provides a selection of drugs based on the scientific rationale and with a shorter cycle of clinical trials, the plasma therapy can be a good source of neutralizing antibody to provide passive immunity from COVID-19 recovered patients, In this review, we provide in-depth analysis on these two approaches currently opted all around the world to treat COVID-19 patients. For this we used "Boolean Operators" such as AND, OR \& NOT to search relevant research articles/reviews from the PUBMED for the repurposed drugs and the convalescent plasma in COVID-19 treatment. The repurposed drugs like repurposed drugs like Chloroquine and hydroxychloroquine, Tenofovir, Remdesivir, Ribavirin, Darunavir, Oseltamivir, Arbidol (Umifenovir), Favipiravir, Anakinra, and Baricitinib are already being used or I trials to treat the COVID-19, and those belong to a diverse category such as anti-malarial/anti-parasitic, antiretroviral/anti-viral, anti-cancer or against rheumatoid arthritis. Although, the vaccine would be an ideal option for providing active immunity against the SARS-CoV-2, but considering 
current situation, the neutralizing antibody through plasma therapy and repurposed drugs are the most viable option against SARS-CoV-2.

Keywords: COVID-19, Vaccine, convalescent plasma, Hydroxychloroquine (HCQ), Cytokine storm syndrome, ASRD, SARS, Rheumatoid arthritis, Pandemic, SARS-CoV-2, herd immunity, vertical transmission, passive immunity 


\section{COVID-19 and SARS-CoV-2 Virus}

An infectious disease COVID-19 caused by a virus belongs to the corona family was first reported in Dec 2019 in the Wuhan city of China. Several other lethal viruses such as severe acute respiratory syndrome-related coronavirus (SARS-CoV) and MERS (Middle Eastern Respiratory Syndrome coronavirus (MERS-CoV) also belong to this family. The first incidence of Corona was reported in the Wuhan city of China. It's a single stranded, enveloped positive sense strand RNA virus. The genome size of coronavirus varies between 27-34 kilobases that are comparatively larger than other RNA viruses. SARS-CoV-2 driven endemic unfurled into a pandemic on $11^{\text {th }}$ of March 2020 by the WHO. So far, a total of seven human coronaviruses (hCoVs) types have been identified as shown in Figure-1. The newest coronavirus strain that caused the current pandemic is known as severe acute respiratory syndrome coronavirus 2 (SARS-CoV-2). The latest member SARS-CoV-2 has similarity close to 70\% with SARS-nCoV. Coronavirus propagates in the cytoplasm of infected cells, which is also the budding site for the vesicles, once the vesicle freed from the cell, the rest of the cell get destroyed[1].

\section{Structure of SARS-CoV-2 Virus}

SARS-CoV-2 RNA codes for four types of significant proteins: specific spike (S), membrane $(\mathrm{M})$, nucleocapsid $(\mathrm{N})$, and envelope (E)[2]. The detailed structure of the virus has been shown in the Figure-2. Among these, E and M proteins are instrumental in viral assembly, and $\mathrm{N}$ protein helps in RNA synthesis. The $\mathrm{S}$ protein is a transmembrane glycoprotein in nature, which facilitates the entry of the SARS-CoV-2 virus into the host by using the signal sequence of N- 
terminal to have access to the endoplasmic reticulum[3]. Due to its gigantic size, it creates distinct spikes on the viral surface.

\section{Mechanism of Entry into the host cells, RAAS, and replication of SARS-CoV-2}

The S protein is cleaved into two polypeptides S1 \& S2 by a protease Transmembrane Serine Protease 2 (TMPRSS2). TMPRSS2 is a furin-like protease contains a single transmembrane domain and single domain for SR TRYPSIN and LDLA domains as well[4]. The gene encoding for this protein is located on 21q22.2. The primary localization of TMPRSS2 is restricted to the plasma membrane. TMPRSS2 is a secretory protein as its presence has been reported in biological fluids like semen[5] and urine[6]. The protein architecture of TMPRSS2 is shown in

Figure-3 .

The priming of the S protein for pathogenicity is carried out by TMPRSS2 in coronaviruses like SARS-CoV, and MERS-CoV[7]. Among those, S1 polypeptide contains the receptor-binding domain (RBD), which binds to the SARS-CoV-2 viral receptor angiotensin-converting enzyme II (ACE2). ACE2 is a carboxypeptidase that contains one transmembrane domain and also one signal peptide $[4,8]$. The gene encoding for this protein is located on Xp22. The primary localization of ACE2 is restricted to the plasma membrane and the secondary localization is extracellular. ACE2 is a secretory protein as its presence has been reported in biological fluids like plasma[5], and urine[6]. The protein architecture of ACE2 protein has been shown in Figure-3. Further, mRNA expression levels in normal tissues are quite heterogeneous[9] as shown in RNAseq derived data in Figure-4. The descending order of mRNA expression level was as follows: small intestine $(93.7 \pm 16.1)$, duodenum $(69 \pm 6.29)$, gall bladder $(32.6 \pm 14.37)$, kidney (30.8 \pm 17.14$)$, testis $(26.9 \pm 8.99)$, heart (12.3 \pm 10.95$)$, thyroid (1.39 \pm 0.928$)$, liver 
(1.29 \pm 0.38$)$, stomach $(1.18 \pm 0.937)$, and lung $(0.345 \pm 0.3)$. SARS-CoV-2 exploits $S$ protein for binding to its receptors ACE2 or DPP4 (dipeptidyl peptidase 4, in bronchial epithelial cells)[10]. The mechanism of entry and replication of SARS-CoV-2 has been shown in Figure-5. DPP4 or CD26 is a protease that contains one signal peptide[4]. The gene encoding for this protein is located on 2q24.3. The primary localization of CD26 is plasma membrane and the secondary localization is extracellular. CD26 is a secretory protein as its presence has been reported in biological fluids like plasma[11], serum[12], semen[5], tears[13], and urine[14]. The protein architecture of CD26 protein has been shown in Figure-3.

The $\mathrm{N}$ protein, which is phosphorylated, binds to SARS-CoV-2 genome in a bead on a string fashion. This protein possibly helps packaging the encapsulate genome into viral particles. The $\mathrm{E}$ protein is a transmembrane protein found in lower concentration and play an important role in assembly \& releasing of the virus, and therefore crucial for pathogenesis. The $\mathrm{M}$ protein is dimer and most abundant one among $\mathrm{M}, \mathrm{N}, \mathrm{S}$ and $\mathrm{E}$ protein.

Hemagglutinin-esterase (HE) exists as dimer protein present in some beta coronaviruses. It binds to sialic acids on the surface of glycoproteins, and increase S protein-mediated entry of virus into the cells, and eventually the virus spread through the mucosa. Unlike other $\beta$-coronaviruses, SARS-CoV-2 infection occurs not only in the mucosal epithelium (nasal depression and pharynx) of the upper respiratory tract but also in other organs like gastric tract. There have been reports of infection in sites other than the respiratory sites as well including heart injury, liver, intestine, diarrhea, and kidney failure.[15]

\section{SARS-CoV-2, Cytokine Storm Syndrome, and Organ failure}


One major issue in COVID-19 cases is the blood upregulation of pro-inflammatory cytokines such as IL-1, IL6, TNF, and interferon $\gamma$. The major source of cytokine production are macrophages as upon activation they can produce cytokines like TNF-a, interleukins including IL6, IL1, IL4, IL13, and IL18. Those further activate the cascade reaction of inflammatory factors that eventually lead to the cytokine storm syndrome (CSS), an uncontrolled response of cytokines. CSS has been reported not only in in avian H5N1 influenza virus, SARS and MERS, but also in other diseases like multiple sclerosis and pancreatitis. Role of different cytokines in relation to COVID-19 has been well documented[16]. Dust cells are present in alveolar region of lungs are macrophages which play an important role in CSS. Type I IFN low levels are common to COVID-19, MERS, and SARS which could suppress Th1, but favor Th2 responses[17].

\section{Transmission of SARS-CoV-2}

The transmission of virus can happen even from a person who shows no symptoms for COVID19 (asymptomatic)[18]. The COVID-19 patients initiates developing symptoms such as mild respiratory issues, and fever in an incubation period between 5 to 6 days which can extend to 114 days [19]. Mode of COVID-19 transmission can be through different routes including contact, droplet, fecal and aerosol transmission[20]. Possibility of vertical transmission of COVID-19 has been suspected. In this case the virus can be transmitted from parents to offspring's via placental barrier, transcytosis of cell-associated virus, during delivery, or through breast-feeding, but vertical transmission in COVID-19 was not reported[21] until recently. The first case of vertical transmission of SARS-CoV-2 was reported from Sassoon General Hospital, Pune, Maharashtra (India)[22]. 
SARS-CoV-2 transmission can occurs in different ways including direct, droplet or aerosol inhalation, contact, through saliva[23], and via fecal-oral route[24]. SARS-CoV-2 transmission can happen by touching contaminated surfaces followed by nose, eyes, or mouth. The stop transmission of SARS-CoV-2 a number of Do's and Don'ts have been recommended by the WHO as well as by agencies like NIH and ICMR. The lists of Do's and don'ts's required to mitigate COVID-19 transmission have been mentioned in the table-1.

Here, we present a systematic review cum meta-analysis conducted to evaluate the significance of currently used treatment options for COVID-19, associated issues, and future challenges in dealing with infection and management of SARS-CoV-2. To achieve this goal, we carried out this study to evaluate the repurposing drugs agents so far used for treatment of COVID-19. For this, we used "Boolean Operators" search criteria in PUBMED to get relevant search outcome [25]. The schema for fetching the data and further filtering of the articles has been shown in

\section{Figure-6.}

We used key words such as:

I. COVID-19 OR Coronavirus $=48,139$

II. COVID-19 AND Repurposing Drugs $=234$

III. COVID-19 AND Repurposing Drugs=232

IV. COVID-19 AND Repurposing Drugs=02

We have searched literature and screened published research articles to further dig-down to list which molecule the repurposed drugs target and what mode whether oral or in form of injection those have been given to the patients. Next, we corroborated the addition information by visiting the https://clinicaltrials.gov/ to get additional information on the clinical trials where the repurposed drugs have been used. The protein architecture of some of the important proteins 
such as ACE2, TMPRSS2, and DPP4 were extracted from the human protein reference database (HPRD) freely accessible at http://hprd.org [4]. Further, the structures of the repurposed drugs were drawn using ChemDraw Professional Version 16.0 software. The rest of the figures were made using Adobe Illustrator CS5 version 15.0.0.

There had been many treatment options adopted worldwide to treat COVID-19 patients. Among those: convalescent plasma therapy, and repurposing the drugs are taking the lead in absence of a vaccine or unavailability of a neutralizing antibody for coronavirus.

Convalescent plasma as a potential therapy for COVID-19: The plasma derived from COVID-19 patients those overcome its infection is referred to as convalescent plasma $(\mathrm{CP}) . \mathrm{CP}$ had been used in the past for treatment of deadly viral diseases such as Severe Acute Respiratory Syndrome (SARS), H1N1, Spanish flu, Ebola, and Middle East Respiratory Syndrome (MERS). The German scientist Emil von Behring got the noble prize in 1901 for the usage of CP in the treatment of diphtheria. The $\mathrm{CP}$ provides may induce the neutralizing antibodies against infectious agents[26]. A must to do task is to get a measurement of titer of the neutralizing antibody in advance prior to giving the plasma to the COVID-19 patients. A titer of $>1: 320$ must be there for the neutralizing antibody [27]. The patients who recovered from COVID-19 can be identified as potential donors if they have: (i) prior diagnosis of COVID-19, (ii) complete resolution of symptoms at least 14 days prior to donation, (iii) a negative PCR result for COVID19, and (iv) with desired SARS-CoV-2 neutralizing antibody titers (optimally >1:320). Although, the donor titer varies in current CP based trials from >1:40 (NCT04374487 from India) to $>1: 320$ (USA: NCT04377672, NCT04373460, NCT04344535, Hungary: NCT04345679), the higher the better. There are more specifics coming up on the criteria for exclusion and inclusion for a donor as well as for a recipient in CP therapy. These are listed 
based on different clinical trials from NIH as well as trials from other countries in Table-1. Though only a handful of studies are there on the usage of CP therapy on COVID-19 patients, those have been summarized in Table-2. The exclusion and inclusion criteria for donors and acceptor have been mentioned in Supplementary Table-1.

In a small study on COVID-19 patients in Guangdong (China), after the $12^{\text {th }}$ day of hospitalization of patients with severe condition $\mathrm{CP}$, was given. Three out of four patients discharged, and the last one was found negative using PCR, two out of four patients able to produce anti-SARS-CoV-2 IgG $\sim 14$ days post-transfusion[28]. A high titer antibody present in the recovered COVID-19 patients must be sufficient enough to bind SARS-CoV-2 and neutralize it to avoid the access to normal cells. One of the major challenges is that $\mathrm{CP}$ is not used alone but in combination with other agents like corticosteroids. The neutralizing antibodies present in the $\mathrm{CP}$ are capable to accelerate the clearance of infected cells as well. CP constituents are comparable of activating the effector mechanism such as activation of complement and phagocytosis[29]. A combination of $\mathrm{CP}$ and corticosteroids can reduce the viral load as well as reduce the excess of inflammatory response[30]. The initial findings from all around the world are encouraging from $\mathrm{CP}$ therapy supporting the evidence that the human anti-SARS-CoV-2 plasma could be able to modulate the virulence exerted by the SARS-CoV-2 via neutralization[31].

\section{Drug repurposing as a potential therapy for COVID-19}

Based on the literature survey, we divided the repurposed drugs that can be used for the trials to treat COVID-19 into five categories: (I) Anti-malarial drugs (II) Drug used for Rheumatoid arthritis (III) Cytokine modulators (IV) Protease Inhibitors (V) Others. Additionally, the details of the currently going on clinical trials are summarized in Supplementary Table-2. 
The drug repurposing offers benefits in terms of time and costs required as compared to the development of new drug from the beginning. The repurposed drugs are approved by the FDA, for their pharmacological properties, safety, and clinical efficacy for a different indication[32]. Therefore when used for the COVID-19 treatments, the toxicity or safety profiles of the repurposed drugs are already known. Therefore, a number of drugs have been repurposed to tackle the COVID-19 across the world. We are presenting basic properties of these drugs, their target and study outcome or at least observations reported in studies all around the world in different studies. We have summarized the repurposed drugs, their target, and information for the diseases originally those were made in Table-3.

Anti-malarial/Anti-Protozoan drugs: The structures of anti-malarial or anti-parasitic drugs have been shown in Figure-7.

Chloroquine phosphate Primarily chloroquine phosphate had been used for the treatment of malaria. It is a quinolone that possesses anti-inflammatory properties, and some time for amebiasis as well. It is also known as chloroquine (CQ). CQ offers an advantage, as it does not pose complications associated with infectious complications exerted by drugs like methotrexate and leflunomide. Evidence based on different studies showed that CQ possesses broad-spectrum anti-viral activities[33, 34]. Both anti-viral as well as anti-inflammatory activities of CQ possibly responsible for CQ's efficacy in treating the pneumonia of COVID-19 patients'[35].

\section{Hydroxychloroquine (HCQ)}

HCQ has other names/synonyms such as Oxychlorochin, Plaquenil, and Oxichloroquine. An in vitro activity against anti-SARS-CoV of HCQ was found to be superior as compared with $\mathrm{CQ}[36]$, and the HCQ clinical profile is also superior to CQ[37]. In terms of side effects when compared CQ with HCQ, it was found that CQ treated patients have some side effects like 
circular defects, retinopathy, diametric retina defects and cardiomyopathy, but patient treated with HCQ have reduced tissue accumulation that could be responsible for lesser adverse events of HCQ as compared with CQ. A high dose for $>5$ yrs of HCQ led to retinopathy development, which is in concordance with the HCQ as a therapy[38, 39].

\section{Emetine}

Emetine is an alkaloid isolated from the flowering plant Carapichea ipecacuanha a member of the family Rubiaceae. Emetine has been used against protozoan infections and also to induce vomiting. Emetine is a translation-inhibiting drug that had been used in amebiasis treatment. It is capable of inhibiting translation machinery of malarial parasite (Plasmodium falciparum) by binding to the $\mathrm{E}$ ribosomal site. This shows anti-viral activity against a wide range of viruses (both DNA and RNA base) including Cytomegalovirus Zika virus, rabies virus, cytomegalovirus, Ebola virus, and HIV-1. Emetine also showed anti-viral activity against hCoV-OC43, SARS$\mathrm{CoV}, \mathrm{hCoV}-\mathrm{NL} 43, \mathrm{MHV}-\mathrm{A} 59$, and MERS-CoV in an in vitro condition. The viral polymerase enzyme and some host proteins are the target of Emetine [18]. It has been recently reported that emetine inhibits the replication of SARS-CoV-2 in $\sim 0.5 \mu \mathrm{M}$ concentration. The in vivo achievable concentration of emetine in plasma is $0.075 \mu \mathrm{g} / \mathrm{mL}(0.156 \mu \mathrm{M})$, lower than the in vitro $\mathrm{EC}_{50}$ against SARS-CoV-2 [19].

Anti-viral drugs: These drugs work against different viruses including retroviruses like HIV-1 and have been proposed to use for the treatment of COVID-19. The structures of selected antiretroviral/anti-viral drugs have been shown in Figure-8.

Favipiravir: Favipiravir is an oral antiviral drug used for the treatment of influenza. Favipiravir came into limelight for Ebola treatment during 2014 epidemic in West Africa as there was no SOC was available. Effectiveness of Favipiravir was also observed for prophylaxis and 
infectious animal models of lethal Ebola virus[40]. It is available with the brand name avigan. The viral RdRP is the target of favipiravir drug. It is an analogue of purine origin and also known as 6-fluoro-3-hydroxy-2-pyrazinecarboxamide or T-705 or Avigan. On an urgent basis, favipiravir had been approved for the clinical trial in adult COVID-19 patients' treatment (2020L00005). SARS-CoV-2 also possess RdRp gene similar to other members of the family (SARS-CoV and MERS-CoV), which makes Favipiravir eligible to test against SARS-CoV-2 virus. It is a pro-drug which upon ribosylation and phosphorylation form an active metabolite intracellularly called T-705RTP or favipiravir ibofuranosyl-5'-triphosphate (T-705RTP), which interfere with the replication of the virus by competing with the naturally occurring purine nucleosides and inhibits the viral RdRP of SARS-CoV-2.

In Shenzhen (China), a clinical trial of favipiravir in COVID-19 patients conducted for evaluation of safety and efficacy (ChiCTR2000029600). A total of 35 patients in the favipiravir arm showed significantly a shorter viral clearance duration in contrast with the control arm containing 45 patients. Further, these findings were corroborated with chest X-rays showing improvement in the favipiravir arm (91.43\% vs 62\%)[41]. In another multi-centric randomized study (ChiCTR200030254), Favipiravir treatment of COVID-19 patients led to an improved recover at $7^{\text {th }}$ day from $55.86 \%$ to $71.43 \%[42]$.

Remdesivir: Remdesivir (also known as GS-5734) is a 1'-cyano-substituted adenosine analogue. It is a pro-drug that inhibits viral RNA polymerases, has shown in vitro activity against coronaviruses like SARS-CoV-2, CoV-229E, SARS-CoV, CoV-OC43, and MERS-CoV[43]. It is a mono phosphoramidate pro-drug possessing wide antiviral spectrum covering filoviruses, coronaviruses, pneumoviruses, and paramyxoviruses. It has been observed that remdesivir in an in vitro condition capable of inhibiting both humans as well as animal coronaviruses including 
SARS-CoV-2. Remdesivir proved to be a superior drug in a lethal murine MERS model as compared with a regimen of IFN-b, and lopinavir-ritonavir combination. Inhibition of SARSCoV-2 was possible in nasal and bronchial epithelial cells of human origin. An EC50 of remdesivir was $0.77 \mu \mathrm{M}$ against SARS-CoV-2 virus[44]. Though role of mutations have been documented in conferring the resistance. F476L and V553L mutations in the RdRPase nsp12 of murine hepatitis virus confer remdesivir resistance.

Alovudine: Alovudine (also known as fluorothymidine) a DNA polymerase inhibitor developed by Medivir is an antiviral agent. Due to toxicity issues, in 2005 after phase II clinical trial, it was discontinued. Alovudine is a nucleoside reverse transcriptase inhibitor analog of thymidine[45]. Alovudine is able to terminate the RNA synthesis SARS-CoV-2 virus, but more work is required before it makes an entry into a clinical trial.

Drug used for Rheumatoid arthritis: The structures of drugs used for rheumatoid arthritis, but now repurposed for treating the COVID-19 patients are shown in Figure-9.

Baricitinib: Baricitinib is an orally available agent used for rheumatoid arthritis. It is sold with the brand name Olumiant. It inhibits the response of inflammatory molecules and cytokine production via modulation of JAK-STAT pathway.[46] It is an active ingredient of olumiant. Baricitinib is a reversible inhibitor of JAK1/JAK2. According to the EU Clinical Trials Register there are already phase-2, \& 3 (2020-001854-23), and phase-IV (2020-001354-22) clinical trials using Baricitinib on COVID-19 patients. Modulation of cytokine dysregulation could affect the host inflammatory response and entry of viruses into the cells. This makes it an ideal agent to be tested in COVID-19 patients[47, 48].

Tofacitinib (Oral): Baricitinib and tofacitinib are first generation JAK inhibitors. Tofacitinib is a small molecule inhibitor of Janus Kinases particularly JAK1/JAK3[49]. It is sold with the brand 
name Xeljanz. It had been used for treatment of RA (moderate to severe form). Tofacitinib is Nacylpiperidine compound. Tofacitinib inhibits STAT also, but in a reversible manner. Tofacitinib subjects to hepatic metabolism through cytochrome CYP3A4 mainly which means a combination of CYP3A4 inhibitors could be tested first in vitro to see if there is a synergistic impact[50].

Ruxolitinib (Oral): It has been used for treatment of moderate to high-risk myelofibrosis. It is sold in the market with the trade name Jakafi or Jakavi. Ruxolitinib is an oral kinase inhibitor that inhibits JAK1 and JAK2. It is also known as INCB01842. Metabolism of ruxolitinib is facilitated by CYP3A4. The chemical constituent of Ruxolitinib belongs to the pyrrolo [2,3d]pyrimidines class of organic compound.

\section{Cytokine modulators}

Tocilizumab: An anti-IL6 blocker targets the IL6 receptor proved to be effective in rheumatoid arthritis treatment[51], and later for juvenile idiopathic arthritis,[52] giant cell arteritis[53]. IL6 is

a bonafide marker for inflammation. It is also known by another famous name Actemra and recently approved by the food $\&$ drug administration (FDA) for testing in a clinical trial for COVID-19 patients. It is a recombinant antibody humanized and of IgG1 class. Actemra is capable of disrupting inflammatory response exerted by IL6 so called cytokine release syndrome (CRS). The efficacy of Actemra was tested on COVID-19 patients at The First Affiliated Hospital of University of Science and Technology of China. Among 21 patients tested, the body temperature return to normal in all the cases. An improvement in respiratory function seen in $100 \%$ of the patients and 20/21 were recovered as seen in CT scan and discharged within 14 days post-tocilizumab treatment. The findings extrapolated on 500 severe or critical patients enrolled in a clinical trial (ChiCTR2000029765)[54]. In contrast, the Italian guidelines suggest that 
tocilizumab use is suitable in patients with major symptoms including when high viral load is over, and patients don, $\mathrm{t}$ have any fever (Apyretic) for $>72 \mathrm{hrs}$ or 7 days post-onset of symptoms, and increased IL6 levels [46].

Anakinra: Anakinra is a recombinant human antagonist of IL1R that has been used in rheumatoid arthritis. These drugs also play an important role in management of CRS. Due to release of IL1R SARS-CoV-2 causes an advanced form of cell death occurs due to inflammation (pyroptosis) and mediated by caspase-1. The repurposed drug anakinra in case of COVID-19 patients in a phase III randomized clinical trial able to reduce both requirement of invasive mechanical ventilation in ICU as well as mortality rate in severe COVID-19 cases without serious side-effects[55].

Adalimumab (Anti-TNF- $\alpha$ agent): It has been earlier used for treatment of Rheumatoid arthritis. The mode of adalimumab for patients is subcutaneous. FDA approved it long back in 2002 for treatment of RH. Biosimilar of adalimumab (Hyrimoz) is also available which is available by the name adalimumab-adaz approved in Oct 2018 by the FDA. Adalimumab binds to $\mathrm{TNF} \alpha$ and leads to inhibition of interaction with receptor of TNF by binding with p55 \& p75. There is a trial going on (ChiCTR2000030089) where one arm includes conventional treatment along with adalimumab[56]. An interesting observation has been mentioned regarding levels TNF- $\alpha$ that it was moderately high in SARS but significantly higher levels in COVID-19 patients.

\section{Protease inhibitors Anti-retroviral / antiviral drugs:}

Lopinavir: Lopinavir is antiretroviral drug used for treatment of HIV patients. It is a protease inhibitor. Lopinavir had been used for treatment of SARS-CoV treatment in combination with ritonavir \& ribavirin in a non-randomized clinical trial. Very few SARS patients' progress to 
ARSD with this treatment as compared to those received only ribavirin and corticosteroids. It was sold by the brand name Kaletra. It is interesting to note that Lopinavir is exclusively given along with ritonavir because lopinavir possess poor oral bioavailability and extensive biotransformation. On other hand, Ritonavir is an inhibitor of the enzymes related to lopinavir metabolism, therefore a co-administration boots the lopinavir exposure and significantly improves the antiviral activity[57]. Hydroxyethylene scaffold is the key in the peptidomimetic of Lopinavir which imitate peptide linkage a target of the HIV-1 protease, but unable to cleave it, therefore prevents the activity of the HIV-1 protease[58]. Finding of a randomized control trial (ChiCTR2000029308) on SARS-CoV-2 showed no significant benefit of lopinavir-ritonavir combination in SARS-CoV-2 patients as compared with SOC[59]. Combining lopinavir with other agents to treat SARS-CoV-2 virus not only increased synergy, but also decreased the lopinavir inhibitory concentration.

Ritonavir: It is another antiretroviral drug used against HIV. It's a protease inhibitor that inhibits the productive cycle of the HIV virus. It is sold with the trade name Norvir. Ritonavir inhibits HIV-1 protease as well as host's cytochrome P450 3A4 enzyme that helps in metabolizing lopinavir. The NIH panel recommended not to use the combination of lopinavir/ritonavir or other HIV protease inhibitors due to unfavorable outcome post-treatment of these agents.

Ribavirin: Ribavirin or tribavirin is an antiviral drug used for Rous sarcoma virus infection, viral hemorrhagic fevers, and hepatitis C. Ribavirin is synthetic guanosine nucleoside that interferes with the viral mRNA synthesis. Ribavirin has been used in combination with interferon beta-1b, lopinavir-ritonavir in a randomized phase-II clinical trial in COVID-19 patients and the early results showed that it was superior to alone lopinavir-ritonavir combination in reducing the symptoms exerted by the virus and shortening shedding of the virus [60]. 
Camostat Mesilate: Camostat mesilate (CM) is an inhibitor of TMPRSS2. It inhibits the serine proteases like TMPRSS2[7]. CM proved to be effective in blocking the spreading and virulence of SARS-CoV in a lethal mouse model[61]. It was observed that CM is capable of blocking the entry of SARS-CoV-2 into the lung cells. Camostat inhibits diver range of proteases including plasmin, trypsin, kallikrein and thrombin[62]. University of Tokyo, Japan planned to conduct a clinical trial on combination of CM and nafamostat on COVID-19 patients. CM was approved in Japan for treatment of pancreatic inflammation[63].

Homoharringtonine: Homoharringtonine is also known as omacetaxine mepesuccinate or HHT. HHT is a cephalotaxine ester. It was isolated from the leave of Cephalotaxus fortunei of family Taxaceae. Omacetaxine received orphan drug status from FDA in March 2006 (according to FDA an orphan drug is the one which is intended to treat a rare diseases which affects $<200,000$ persons in the United States) for treatment of chronic myeloid leukemia patients particularly those who found to be resistant to $>2$ tyrosine kinase inhibitors. HHT shows anti-cancer activity via inhibition of translation by binding to ribosomal site-A. This forces the cells to loss proteins like MCL1 and c-MYC (both with short half life), crucial for leukemia cell's survival. HHT showed activity against large number of viruses including pseudorabies virus, rabies virus, hepatitis B virus, Newcastle disease virus, and echovirus 1[64]. In an in vitro screening in Vero E6 cells, HHT inhibited SARS-CoV-2 replication at an EC50 of $<100 \mu \mathrm{M}[65]$.

\section{An urgent requirement and challenges for more treatment options for COVID-19:}

Vaccine Development for COVID-19: a large of pharma giants as well as virologist all around the world is joining the hands to develop vaccine against SARS-CoV-2. These vaccines includes from mRNA vaccine, inactivated virus vaccine, DNA vaccine recombinant protein vaccine, to 
viral vector-based vaccine. A number of potential candidates for vaccines are in pre-clinical studies in different parts of the world including USA, Russia, China, UK, and India. Regardless which of these countries get success and finally a vaccine approved, the first challenge is whether the country is willing to share it with rest of the world, second challenge is to produce billions of doses required all around the world, and third challenge which is most crucial is the frequent mutation rate in RNA based viruses like in HIV-1 if those kind of mutations occurs in SARS-CoV-2 and able to modulate the immune response. So, overcoming these challenges requires close collaboration between pharma giants, regulatory bodies like FDA, active involvement and cooperation of the scientific community, and healthcare systems.

II. Development of antibodies neutralizing the virus: Most of the anti-SARS-CoV novel antibodies (nAbs) have been targeted against S protein, RBD [66], S2 subunit, and S1/S2 proteolytic cleavage sites. Some nAbs like S230.15, m396, S109.8 and S227.14 showed neutralizing activity against human, raccoon dog, and palm civet but none of these have been evaluated in clinical studies. Antibodies like $80 \mathrm{R}(\mathrm{scFv}$ or mAb) capable of neutralizing the infection of SARS-CoV via blockage of RBD-ACE2 interaction [67]. There is a high sequence identify for $\mathrm{S}$ protein between SARS-CoV-2 and SARS-CoV[68]. This suggests a cross neutralizing / cross-reactivity of nAbs between SARS-CoV \& SARS-CoV-2 infection. The SARS-CoV mAB CR3022 (RBD-specific) could possibly bind to SARS-CoV-2 RBD as SARSCoV \& SARS-CoV-2 have similarity in their RBDs[69]. Different fragments like S1-NTD, S2, and RBD have been used as target for development of nAbs, similar strategy could be adopted for SARS-CoV-2. CP is currently in use for treatment of COVID-19 patients, but non-nAbs targeting other regions than $\mathrm{RBD}$ of $\mathrm{S}$ protein can create antibody-dependent enhancement (ADE) effect on virulence as well as on the disease[70]. 
Mesenchymal Stem Cell Therapy for COVID-19: Stem cell therapy proven to be very useful in treating a number of diseases including cancer[71], and diabetes[72]. Mesenchymal cells (MSC) consist of low invasive nature and high proliferation rate, and additionally devoid of ethical \& social issues that makes it as the preferred therapeutic option over others[73]. MSCs play an important role in immunomodulatory effects via secreting many types of cytokines by paracrine secretion or make direct interactions with immune cells. The source of MSCs can be peripheral blood (PB), bone marrow (BM), adipose tissues (AT, buccal fat pad, abdominal fat, \& infrapatellar fat pad), placenta, umbilical cord, Warton jelly, amniotic fluid (AF), and blood cord. Therefore, it seems MSCs-based therapy may possibly be an ideal candidate for clinical trials or at least the combination of treatment to treat COVID-19 patients.

MSC therapy was applied in COVID-19 patients on seven patients. The levels of peripheral lymphocyte were increased, and on day 6 cytokine secreting cells $(\mathrm{CXCR} 3+\mathrm{CD} 4+\mathrm{T}, \mathrm{CXCR} 3+$ CD8+ T, and NK CXCR3+ cells) were disappeared. The Dendritic cell population and IL10 were increased, but TNF- $\alpha$ level was decreased. The MSCs were found to be negative for ACE2 and TMPRSS2 suggesting there was no SARS-CoV-2 infection[74].

In addition, recently a case study was reported in China on a female patient with an acute COVID-19 syndrome that the results of laboratory tests and CT images provided extremely effective results after 21 days of treatment with umbilical cord MSCs. Upon treatment with MSCs, an increase in lymphocyte and a decrease both in WBCs and neutrophils was observed. Some T cell surface markers like CD3, CD4, and CD8 were increased. CT scans showed that the pneumonia was cleared[75]. Including the ground-glass opacity in the lung, the other typical diagnosis characteristic of critically ill patients was a significant decrease in lymphocytes along 
with the increase of neutrophils. A handful studies on MSCs show promising results in the treatment of COVID-19 patients. Though on limited number of patients, but these studies showed that MSC therapy alone or in combination with other drugs. Agents could be an option to treat SARS-CoV-2 infected patients.

\section{CONCLUSION}

The existence of SARS-CoV-2 was reported in 2019. Since then it posed a threat to mankind around the world. Hastening of treatment options for COVID-19 brought nothing so far but we have to look on old treatment option as savior because we know convalescent plasma therapy and repurposing drugs approaches had been used in the past in crisis period. While massive scale efforts to make a suitable vaccine are on the way, time being number of drugs used for other diseases have been currently repurposed to tackle the COVID-19 pandemic. As the time frame to get a vaccine is critical because from selection of the suitable target to testing in the animals and then eventually assessment at different QC levels in different clinical trials phases is crucial before duration of a vaccine from starting to entry in the market and eventually into the clinic is very crucial and the scientific/biomedical community can not afford that. While we wait for a vaccine to come into picture, convalescent plasma therapy, and repurposing the drugs treatment options proven to be suitable (if not perfect). We need to have suitable vaccine development, neutralizing nABs antibody as prophylactic and therapeutic, and mesenchymal stem cell based treatment options for effectively dealing with COVID-19. Until, an ideal treatment comes into picture, people must follow proper caution such as wearing masks, follow social distancing, and as much as possible do activities, which could be afforded through online mode/route. 


\section{Ethical statement}

The data included in the study was collected form published studied on COVID-19. The study does not involve any human subjects, samples or cell lines.

\section{ACKNOWLEDGEMENTS}

Not applicable

\section{Funding}

MKK is recipient of the TARE fellowship (Grant \# TAR/2018/001054) from the Science and Engineering Research Board (SERB), Department of Science and Technology, Government of India.

\section{Availability of data and material}

All data generated and analyzed during our study are included in the published article.

\section{Authorship contributions}

MKK and AH conceived and guided the research. MKK, AKS, PK, AK, GT, \& AT carried out the carried out exhaustive search on the data. AKS, PK, AK, GT, AT, KM, PCM, \& MKK analyzed and interpreted the data. MKK wrote the manuscripts. All the authors read, critically evaluated, gave their feedback, and edited the manuscript.

\section{Disclosure of Potential Conflicts of Interest}

The other authors declared no potential conflicts of interests. 


\section{Competing Financial Interests statement}

There is NO competing financial interest associated with this manuscript.

\section{Consent for publication}

Not applicable. 


\section{REFERENCES:}

1. Kahn JS and Mclntosh K (2005) History and recent advances in coronavirus discovery. Pediatr Infect Dis J 24:S223-7, discussion S226. doi: 10.1097/01.inf.0000188166.17324.60

2. Song Z, Xu Y, Bao L, Zhang L, Yu P, Qu Y, Zhu H, Zhao W, Han Y and Qin C (2019) From SARS to MERS, Thrusting Coronaviruses into the Spotlight. Viruses 11. doi: 10.3390/v11010059

3. Raj K, Rohit, Ghosh A and Singh S (2020) Coronavirus as silent killer: recent advancement to pathogenesis, therapeutic strategy and future perspectives. Virusdisease:1-9. doi: 10.1007/s13337-02000580-4

4. Keshava Prasad TS, Goel R, Kandasamy K, Keerthikumar S, Kumar S, Mathivanan S, Telikicherla D, Raju R, Shafreen B, Venugopal A, Balakrishnan L, Marimuthu A, Banerjee S, Somanathan DS, Sebastian A, Rani S, Ray S, Harrys Kishore CJ, Kanth S, Ahmed M, Kashyap MK, Mohmood R, Ramachandra YL, Krishna V, Rahiman BA, Mohan S, Ranganathan P, Ramabadran S, Chaerkady R and Pandey ACP (2009) Human Protein Reference Database--2009 update. Nucleic Acids Res 37:D767-72.

5. Pilch B and Mann M (2006) Large-scale and high-confidence proteomic analysis of human seminal plasma. Genome Biol 7:R40. doi: 10.1186/gb-2006-7-5-r40

6. Adachi J, Kumar C, Zhang Y, Olsen JV and Mann M (2006) The human urinary proteome contains more than 1500 proteins, including a large proportion of membrane proteins. Genome Biol 7:R80. doi: 10.1186/gb-2006-7-9-R80

7. Hoffmann $M$, Kleine-Weber $H$, Schroeder $S$, Kruger $N$, Herrler $T$, Erichsen $S$, Schiergens TS, Herrler G, Wu NH, Nitsche A, Muller MA, Drosten C and Pohlmann S (2020) SARS-CoV-2 Cell Entry Depends on ACE2 and TMPRSS2 and Is Blocked by a Clinically Proven Protease Inhibitor. Cell 181:271280 e8. doi: 10.1016/j.cell.2020.02.052

8. Rao R, Husain A, Bharti AC and Kashyap MK (2019) Discovery of a Novel Connecting Link between Renin-Angiotensin System and Cancer in Barrett's Esophagus by Proteomic Screening. Proteomics Clin Appl:e1900006. doi: 10.1002/prca.201900006

9. Fagerberg L, Hallstrom BM, Oksvold P, Kampf C, Djureinovic D, Odeberg J, Habuka M, Tahmasebpoor S, Danielsson A, Edlund K, Asplund A, Sjostedt E, Lundberg E, Szigyarto CA, Skogs M, Takanen JO, Berling H, Tegel H, Mulder J, Nilsson P, Schwenk JM, Lindskog C, Danielsson F, Mardinoglu A, Sivertsson A, von Feilitzen K, Forsberg M, Zwahlen M, Olsson I, Navani S, Huss M, Nielsen J, Ponten F and Uhlen $M$ (2014) Analysis of the human tissue-specific expression by genome-wide integration of transcriptomics and antibody-based proteomics. Mol Cell Proteomics 13:397-406. doi: 10.1074/mcp.M113.035600

10. Dalan R (2020) Is DPP4 inhibition a comrade or adversary in COVID-19 infection. Diabetes Res Clin Pract 164:108216. doi: 10.1016/j.diabres.2020.108216

11. Sedo A, Malik R, Vicar J, Simanek V and Ulrichova J (2003) Quaternary benzo[c]phenanthridine alkaloids as inhibitors of dipeptidyl peptidase IV-like activity baring enzymes in human blood plasma and glioma cell lines. Physiol Res 52:367-72.

12. Iwaki-Egawa $S$, Watanabe $Y$, Kikuya $Y$ and Fujimoto $Y$ (1998) Dipeptidyl peptidase IV from human serum: purification, characterization, and N-terminal amino acid sequence. J Biochem 124:428-33. doi: 10.1093/oxfordjournals.jbchem.a022130

13. de Souza GA, Godoy LM and Mann M (2006) Identification of 491 proteins in the tear fluid proteome reveals a large number of proteases and protease inhibitors. Genome Biol 7:R72. doi: 10.1186/gb-2006-7-8-R72

14. Khan A and Packer NH (2006) Simple urinary sample preparation for proteomic analysis. J Proteome Res 5:2824-38. doi: 10.1021/pr060305y

15. Yang HY and Duan GC (2020) [Analysis on the epidemic factors for the Corona Virus Disease]. Zhonghua Yu Fang Yi Xue Za Zhi 54:E021. doi: 10.3760/cma.j.cn112150-20200227-00196 
16. Feldmann M, Maini RN, Woody JN, Holgate ST, Winter G, Rowland M, Richards D and Hussell T (2020) Trials of anti-tumour necrosis factor therapy for COVID-19 are urgently needed. Lancet 395:14071409. doi: 10.1016/S0140-6736(20)30858-8

17. Torres T and Puig L (2020) Managing Cutaneous Immune-Mediated Diseases During the COVID19 Pandemic. Am J Clin Dermatol. doi: 10.1007/s40257-020-00514-2

18. Liu Z, Magal P, Seydi O and Webb G (2020) A COVID-19 epidemic model with latency period. Infect Dis Model. doi: 10.1016/j.idm.2020.03.003

19. Lauer SA, Grantz KH, Bi Q, Jones FK, Zheng Q, Meredith HR, Azman AS, Reich NG and Lessler J (2020) The Incubation Period of Coronavirus Disease 2019 (COVID-19) From Publicly Reported Confirmed Cases: Estimation and Application. Ann Intern Med 172:577-582. doi: 10.7326/M20-0504

20. McDermott CV, Alicic RZ, Harden N, Cox EJ and Scanlan JM (2020) Put a lid on it: Are faecal bioaerosols a route of transmission for SARS-CoV-2? J Hosp Infect. doi: 10.1016/j.jhin.2020.04.024

21. Chen H, Guo J, Wang C, Luo F, Yu X, Zhang W, Li J, Zhao D, Xu D, Gong Q, Liao J, Yang H, Hou W and Zhang $Y$ (2020) Clinical characteristics and intrauterine vertical transmission potential of COVID-19 infection in nine pregnant women: a retrospective review of medical records. Lancet 395:809-815. doi: 10.1016/S0140-6736(20)30360-3

22. HIndu T (2020) Vertical transmission of an infection occurs from a mother to the child in the uterus, through the placenta. The Hindu, India

23. Khan S, Liu J and Xue M (2020) Transmission of SARS-CoV-2, Required Developments in Research and Associated Public Health Concerns. Front Med (Lausanne) 7:310. doi: 10.3389/fmed.2020.00310

24. Chan JF, Yuan S, Kok KH, To KK, Chu H, Yang J, Xing F, Liu J, Yip CC, Poon RW, Tsoi HW, Lo SK, Chan KH, Poon VK, Chan WM, Ip JD, Cai JP, Cheng VC, Chen H, Hui CK and Yuen KY (2020) A familial cluster of pneumonia associated with the 2019 novel coronavirus indicating person-to-person transmission: a study of a family cluster. Lancet 395:514-523. doi: 10.1016/S0140-6736(20)30154-9

25. Tungekar A, Mandarthi S, Mandaviya PR, Gadekar VP, Tantry A, Kotian S, Reddy J, Prabha D, Bhat S, Sahay S, Mascarenhas R, Badkillaya RR, Nagasampige MK, Yelnadu M, Pawar H, Hebbar P and Kashyap MK (2018) ESCC ATLAS: A population wide compendium of biomarkers for Esophageal Squamous Cell Carcinoma. Sci Rep 8:12715. doi: 10.1038/s41598-018-30579-3

26. Marson P, Cozza A and De Silvestro G (2020) The true historical origin of convalescent plasma therapy. Transfus Apher Sci:102847. doi: 10.1016/j.transci.2020.102847

27. Bloch EM, Shoham S, Casadevall A, Sachais BS, Shaz B, Winters JL, van Buskirk C, Grossman BJ, Joyner M, Henderson JP, Pekosz A, Lau B, Wesolowski A, Katz L, Shan H, Auwaerter PG, Thomas D, Sullivan DJ, Paneth N, Gehrie E, Spitalnik S, Hod E, Pollack L, Nicholson WT, Pirofski LA, Bailey JA and Tobian AA (2020) Deployment of convalescent plasma for the prevention and treatment of COVID-19. J Clin Invest. doi: 10.1172/JCI138745

28. Zhang B, Liu S, Tan T, Huang W, Dong Y, Chen L, Chen Q, Zhang L, Zhong Q, Zhang X, Zou Y and Zhang S (2020) Treatment With Convalescent Plasma for Critically III Patients With Severe Acute Respiratory Syndrome Coronavirus 2 Infection. Chest 158:e9-e13. doi: 10.1016/j.chest.2020.03.039

29. Cunningham AC, Goh HP and Koh D (2020) Treatment of COVID-19: old tricks for new challenges. Crit Care 24:91. doi: 10.1186/s13054-020-2818-6

30. Ahn JY, Sohn Y, Lee SH, Cho Y, Hyun JH, Baek YJ, Jeong SJ, Kim JH, Ku NS, Yeom JS, Roh J, Ahn MY, Chin BS, Kim YS, Lee H, Yong D, Kim HO, Kim S and Choi JY (2020) Use of Convalescent Plasma Therapy in Two COVID-19 Patients with Acute Respiratory Distress Syndrome in Korea. J Korean Med Sci 35:e149. doi: 10.3346/jkms.2020.35.e149

31. Teixeira da Silva JA (2020) Convalescent plasma: A possible treatment of COVID-19 in India. Med J Armed Forces India. doi: 10.1016/j.mjafi.2020.04.006

32. Khalili JS, Zhu H, Mak NSA, Yan Y and Zhu Y (2020) Novel coronavirus treatment with ribavirin: Groundwork for an evaluation concerning COVID-19. J Med Virol. doi: 10.1002/jmv.25798 
33. Savarino A, Boelaert JR, Cassone A, Majori G and Cauda R (2003) Effects of chloroquine on viral infections: an old drug against today's diseases? Lancet Infect Dis 3:722-7. doi: 10.1016/s14733099(03)00806-5

34. Yan Y, Zou Z, Sun Y, Li X, Xu KF, Wei Y, Jin N and Jiang C (2013) Anti-malaria drug chloroquine is highly effective in treating avian influenza A H5N1 virus infection in an animal model. Cell Res 23:300-2. doi: 10.1038/cr.2012.165

35. Gao J, Tian Z and Yang $X$ (2020) Breakthrough: Chloroquine phosphate has shown apparent efficacy in treatment of COVID-19 associated pneumonia in clinical studies. Biosci Trends 14:72-73. doi: 10.5582/bst.2020.01047

36. Biot C, Daher W, Chavain N, Fandeur T, Khalife J, Dive D and De Clercq E (2006) Design and synthesis of hydroxyferroquine derivatives with antimalarial and antiviral activities. J Med Chem 49:2845-9. doi: 10.1021/jm0601856

37. Marmor MF, Kellner U, Lai TY, Melles RB, Mieler WF and American Academy of O (2016) Recommendations on Screening for Chloroquine and Hydroxychloroquine Retinopathy (2016 Revision). Ophthalmology 123:1386-94. doi: 10.1016/j.ophtha.2016.01.058

38. Gautret P, Lagier JC, Parola P, Hoang VT, Meddeb L, Mailhe M, Doudier B, Courjon J, Giordanengo V, Vieira VE, Tissot Dupont H, Honore S, Colson P, Chabriere E, La Scola B, Rolain JM, Brouqui $P$ and Raoult D (2020) Hydroxychloroquine and azithromycin as a treatment of COVID-19: results of an open-label non-randomized clinical trial. Int J Antimicrob Agents:105949. doi: 10.1016/j.ijantimicag.2020.105949

39. Zhou D, Dai SM and Tong Q (2020) COVID-19: a recommendation to examine the effect of hydroxychloroquine in preventing infection and progression. J Antimicrob Chemother 75:1667-1670. doi: 10.1093/jac/dkaa114

40. Oestereich L, Ludtke A, Wurr S, Rieger T, Munoz-Fontela C and Gunther S (2014) Successful treatment of advanced Ebola virus infection with T-705 (favipiravir) in a small animal model. Antiviral Res 105:17-21. doi: 10.1016/j.antiviral.2014.02.014

41. Coomes EA and Haghbayan H (2020) Favipiravir, an antiviral for COVID-19? J Antimicrob Chemother 75:2013-2014. doi: 10.1093/jac/dkaa171

42. Du YX and Chen XP (2020) Favipiravir: Pharmacokinetics and Concerns About Clinical Trials for 2019-nCoV Infection. Clin Pharmacol Ther 108:242-247. doi: 10.1002/cpt.1844

43. de Wit E, Feldmann F, Cronin J, Jordan R, Okumura A, Thomas T, Scott D, Cihlar T and Feldmann $H$ (2020) Prophylactic and therapeutic remdesivir (GS-5734) treatment in the rhesus macaque model of MERS-CoV infection. Proc Natl Acad Sci U S A 117:6771-6776. doi: 10.1073/pnas.1922083117

44. Wang M, Cao R, Zhang L, Yang X, Liu J, Xu M, Shi Z, Hu Z, Zhong W and Xiao G (2020) Remdesivir and chloroquine effectively inhibit the recently emerged novel coronavirus (2019-nCoV) in vitro. Cell Res 30:269-271. doi: 10.1038/s41422-020-0282-0

45. Yehudai D, Liyanage SU, Hurren R, Rizoska B, Albertella M, Gronda M, Jeyaraju DV, Wang X, Barghout SH, MacLean N, Siriwardena TP, Jitkova Y, Targett-Adams P and Schimmer AD (2019) The thymidine dideoxynucleoside analog, alovudine, inhibits the mitochondrial DNA polymerase gamma, impairs oxidative phosphorylation and promotes monocytic differentiation in acute myeloid leukemia. Haematologica 104:963-972. doi: 10.3324/haematol.2018.195172

46. Sarzi-Puttini P, Giorgi V, Sirotti S, Marotto D, Ardizzone S, Rizzardini G, Antinori S and Galli M (2020) COVID-19, cytokines and immunosuppression: what can we learn from severe acute respiratory syndrome? Clin Exp Rheumatol 38:337-342.

47. Richardson P, Griffin I, Tucker C, Smith D, Oechsle O, Phelan A and Stebbing J (2020) Baricitinib as potential treatment for 2019-nCoV acute respiratory disease. Lancet 395:e30-e31. doi: 10.1016/S0140-6736(20)30304-4 
48. Stebbing J, Phelan A, Griffin I, Tucker C, Oechsle O, Smith D and Richardson P (2020) COVID-19: combining antiviral and anti-inflammatory treatments. Lancet Infect Dis 20:400-402. doi: 10.1016/S1473-3099(20)30132-8

49. Fridman JS, Scherle PA, Collins R, Burn TC, Li Y, Li J, Covington MB, Thomas B, Collier P, Favata MF, Wen X, Shi J, McGee R, Haley PJ, Shepard S, Rodgers JD, Yeleswaram S, Hollis G, Newton RC, Metcalf $B$, Friedman SM and Vaddi K (2010) Selective inhibition of JAK1 and JAK2 is efficacious in rodent models of arthritis: preclinical characterization of INCB028050. J Immunol 184:5298-307. doi: 10.4049/jimmunol.0902819

50. Angelini J, Talotta R, Roncato R, Fornasier G, Barbiero G, Dal Cin L, Brancati S and Scaglione F (2020) JAK-Inhibitors for the Treatment of Rheumatoid Arthritis: A Focus on the Present and an Outlook on the Future. Biomolecules 10. doi: 10.3390/biom10071002

51. Best JH, Vlad SC, Tominna L and Abbass I (2020) Real-World Persistence with Tocilizumab Compared to Other Subcutaneous Biologic Disease-Modifying Antirheumatic Drugs Among Patients with Rheumatoid Arthritis Switching from Another Biologic. Rheumatol Ther. doi: 10.1007/s40744-02000201-y

52. Kessler EA, Vora SS and Verbsky JW (2012) Risk of significant cytopenias after treatment with tocilizumab in systemic juvenile arthritis patients with a history of macrophage activation syndrome. Pediatr Rheumatol Online J 10:30. doi: 10.1186/1546-0096-10-30

53. Mariano VJ and Frishman WH (2018) Tocilizumab in Giant Cell Arteritis. Cardiol Rev 26:321-330. doi: $10.1097 / C R D .0000000000000204$

54. Fu B, Xu X and Wei H (2020) Why tocilizumab could be an effective treatment for severe COVID19? J Transl Med 18:164. doi: 10.1186/s12967-020-02339-3

55. Huet T BH, Voisin O, et al. (2020) Anakinra for severe forms of COVID-19: a cohort study. The Lancet Rheumatology 2:E393-E400.

56. Lythgoe MP and Middleton P (2020) Ongoing Clinical Trials for the Management of the COVID19 Pandemic. Trends Pharmacol Sci 41:363-382. doi: 10.1016/j.tips.2020.03.006

57. use FADPKIrfo.

58. De Clercq E (2009) Anti-HIV drugs: 25 compounds approved within 25 years after the discovery of HIV. Int J Antimicrob Agents 33:307-20. doi: 10.1016/j.ijantimicag.2008.10.010

59. Cao J, Forrest JC and Zhang X (2015) A screen of the NIH Clinical Collection small molecule library identifies potential anti-coronavirus drugs. Antiviral Res 114:1-10. doi: 10.1016/j.antiviral.2014.11.010

60. Hung IF, Lung KC, Tso EY, Liu R, Chung TW, Chu MY, Ng YY, Lo J, Chan J, Tam AR, Shum HP, Chan V, Wu AK, Sin KM, Leung WS, Law WL, Lung DC, Sin S, Yeung P, Yip CC, Zhang RR, Fung AY, Yan EY, Leung KH, Ip JD, Chu AW, Chan WM, Ng AC, Lee R, Fung K, Yeung A, Wu TC, Chan JW, Yan WW, Chan WM, Chan JF, Lie AK, Tsang OT, Cheng VC, Que TL, Lau CS, Chan KH, To KK and Yuen KY (2020) Triple combination of interferon beta-1b, lopinavir-ritonavir, and ribavirin in the treatment of patients admitted to hospital with COVID-19: an open-label, randomised, phase 2 trial. Lancet 395:1695-1704. doi: 10.1016/S01406736(20)31042-4

61. Uno Y (2020) Camostat mesilate therapy for COVID-19. Intern Emerg Med. doi: 10.1007/s11739020-02345-9

62. Coote K, Atherton-Watson HC, Sugar R, Young A, MacKenzie-Beevor A, Gosling M, Bhalay G, Bloomfield G, Dunstan A, Bridges RJ, Sabater JR, Abraham WM, Tully D, Pacoma R, Schumacher A, Harris $J$ and Danahay H (2009) Camostat attenuates airway epithelial sodium channel function in vivo through the inhibition of a channel-activating protease. J Pharmacol Exp Ther 329:764-74. doi: 10.1124/jpet.108.148155

63. Yamauchi J, Takeda K, Shibuya K, Sunamura M and Matsuno S (2001) Continuous regional application of protease inhibitor in the treatment of acute pancreatitis. An experimental study using closed duodenal obstruction model in dogs. Pancreatology 1:662-7. doi: 10.1159/000055878 
64. Andersen PI, Krpina K, lanevski A, Shtaida N, Jo E, Yang J, Koit S, Tenson T, Hukkanen V, Anthonsen MW, Bjoras M, Evander M, Windisch MP, Zusinaite E and Kainov DE (2019) Novel Antiviral Activities of Obatoclax, Emetine, Niclosamide, Brequinar, and Homoharringtonine. Viruses 11. doi: 10.3390/v11100964

65. Choy KT, Wong AY, Kaewpreedee P, Sia SF, Chen D, Hui KPY, Chu DKW, Chan MCW, Cheung PP, Huang $X$, Peiris M and Yen HL (2020) Remdesivir, lopinavir, emetine, and homoharringtonine inhibit SARS-CoV-2 replication in vitro. Antiviral Res 178:104786. doi: 10.1016/j.antiviral.2020.104786

66. Zhu Z, Chakraborti S, He Y, Roberts A, Sheahan T, Xiao X, Hensley LE, Prabakaran P, Rockx B, Sidorov IA, Corti D, Vogel L, Feng Y, Kim JO, Wang LF, Baric R, Lanzavecchia A, Curtis KM, Nabel GJ, Subbarao K, Jiang $S$ and Dimitrov DS (2007) Potent cross-reactive neutralization of SARS coronavirus isolates by human monoclonal antibodies. Proc Natl Acad Sci U S A 104:12123-8. doi: 10.1073/pnas.0701000104

67. Rockx B, Corti D, Donaldson E, Sheahan T, Stadler K, Lanzavecchia A and Baric R (2008) Structural basis for potent cross-neutralizing human monoclonal antibody protection against lethal human and zoonotic severe acute respiratory syndrome coronavirus challenge. J Virol 82:3220-35. doi: 10.1128/JVI.02377-07

68. Zhou P, Yang XL, Wang XG, Hu B, Zhang L, Zhang W, Si HR, Zhu Y, Li B, Huang CL, Chen HD, Chen J, Luo Y, Guo H, Jiang RD, Liu MQ, Chen Y, Shen XR, Wang X, Zheng XS, Zhao K, Chen QJ, Deng F, Liu LL, Yan B, Zhan FX, Wang YY, Xiao GF and Shi ZL (2020) A pneumonia outbreak associated with a new coronavirus of probable bat origin. Nature 579:270-273. doi: 10.1038/s41586-020-2012-7

69. Lan J, Ge J, Yu J, Shan S, Zhou H, Fan S, Zhang Q, Shi X, Wang Q, Zhang L and Wang X (2020) Structure of the SARS-CoV-2 spike receptor-binding domain bound to the ACE2 receptor. Nature 581:215-220. doi: 10.1038/s41586-020-2180-5

70. Du L, He Y, Zhou Y, Liu S, Zheng BJ and Jiang S (2009) The spike protein of SARS-CoV--a target for vaccine and therapeutic development. Nat Rev Microbiol 7:226-36. doi: 10.1038/nrmicro2090

71. Dazzi F and Horwood NJ (2007) Potential of mesenchymal stem cell therapy. Curr Opin Oncol 19:650-5. doi: 10.1097/CCO.0b013e3282f0e116

72. Moreira A, Kahlenberg S and Hornsby P (2017) Therapeutic potential of mesenchymal stem cells for diabetes. J Mol Endocrinol 59:R109-R120. doi: 10.1530/JME-17-0117

73. Golchin A, Farahany TZ, Khojasteh A, Soleimanifar F and Ardeshirylajimi A (2019) The Clinical Trials of Mesenchymal Stem Cell Therapy in Skin Diseases: An Update and Concise Review. Curr Stem Cell Res Ther 14:22-33. doi: 10.2174/1574888X13666180913123424

74. Leng Z, Zhu R, Hou W, Feng Y, Yang Y, Han Q, Shan G, Meng F, Du D, Wang S, Fan J, Wang W, Deng L, Shi H, Li H, Hu Z, Zhang F, Gao J, Liu H, Li X, Zhao Y, Yin K, He X, Gao Z, Wang Y, Yang B, Jin R, Stambler I, Lim LW, Su H, Moskalev A, Cano A, Chakrabarti S, Min KJ, Ellison-Hughes G, Caruso C, Jin K and Zhao RC (2020) Transplantation of ACE2(-) Mesenchymal Stem Cells Improves the Outcome of Patients with COVID-19 Pneumonia. Aging Dis 11:216-228. doi: 10.14336/AD.2020.0228

75. Liang B CJ, Li T, Wu HY, Yang WJ, Li YJ, (2020) Clinical remission of a critically ill COVID-19 patient treated by human umbilical cord mesenchymal stem cells. chinaXiv:202002.00084.

76. Brake SJ, Barnsley K, Lu W, McAlinden KD, Eapen MS and Sohal SS (2020) Smoking Upregulates Angiotensin-Converting Enzyme-2 Receptor: A Potential Adhesion Site for Novel Coronavirus SARS-CoV2 (Covid-19). J Clin Med 9. doi: 10.3390/jcm9030841

77. Giwa AL, Desai A and Duca A (2020) Novel 2019 coronavirus SARS-CoV-2 (COVID-19): An updated overview for emergency clinicians. Emerg Med Pract 22:1-28.

78. Tirupathi R, Bharathidasan K, Palabindala V, Salim SA and Al-Tawfiq JA (2020) Comprehensive review of mask utility and challenges during the COVID-19 pandemic. Infez Med 28:57-63.

79. Berardi A, Perinelli DR, Merchant HA, Bisharat L, Basheti IA, Bonacucina G, Cespi M and Palmieri GF (2020) Hand sanitisers amid CoViD-19: A critical review of alcohol-based products on the market and 
formulation approaches to respond to increasing demand. Int J Pharm 584:119431. doi: 10.1016/j.ijpharm.2020.119431

80. Maclntyre CR and Wang Q (2020) Physical distancing, face masks, and eye protection for prevention of COVID-19. Lancet 395:1950-1951. doi: 10.1016/S0140-6736(20)31183-1

81. Wilder-Smith A and Freedman DO (2020) Isolation, quarantine, social distancing and community containment: pivotal role for old-style public health measures in the novel coronavirus (2019-nCoV) outbreak. J Travel Med 27. doi: 10.1093/jtm/taaa020

82. West R, Michie S, Rubin GJ and Amlot R (2020) Applying principles of behaviour change to reduce SARS-CoV-2 transmission. Nat Hum Behav 4:451-459. doi: 10.1038/s41562-020-0887-9

83. Santos C, Kieszak S, Wang A, Law R, Schier J and Wolkin A (2017) Reported Adverse Health Effects in Children from Ingestion of Alcohol-Based Hand Sanitizers - United States, 2011-2014. MMWR Morb Mortal Wkly Rep 66:223-226. doi: 10.15585/mmwr.mm6608a5

84. Muller O, Neuhann F and Razum O (2020) [Epidemiology and control of COVID-19]. Dtsch Med Wochenschr 145:670-674. doi: 10.1055/a-1162-1987

85. Adhikari SP, Meng S, Wu YJ, Mao YP, Ye RX, Wang QZ, Sun C, Sylvia S, Rozelle S, Raat H and Zhou H (2020) Epidemiology, causes, clinical manifestation and diagnosis, prevention and control of coronavirus disease (COVID-19) during the early outbreak period: a scoping review. Infect Dis Poverty 9:29. doi: 10.1186/s40249-020-00646-x

86. Ozma MA, Maroufi P, Khodadadi E, Kose S, Esposito I, Ganbarov K, Dao S, Esposito S, Dal T, Zeinalzadeh E and Kafil HS (2020) Clinical manifestation, diagnosis, prevention and control of SARS-CoV2 (COVID-19) during the outbreak period. Infez Med 28:153-165.

87. Kulkarni P, Kodad S and Mahadevappa M (2020) Covid-19 and Namaste. Influenza Other Respir Viruses. doi: 10.1111/irv.12746

88. Pascarella G, Strumia A, Piliego C, Bruno F, Del Buono R, Costa F, Scarlata S and Agro FE (2020) COVID-19 diagnosis and management: a comprehensive review. J Intern Med 288:192-206. doi: 10.1111/joim.13091

89. Ming LC, Untong N, Aliudin NA, Osili N, Kifli N, Tan CS, Goh KW, Ng PW, Al-Worafi YM, Lee KS and Goh HP (2020) Mobile Health Apps on COVID-19 Launched in the Early Days of the Pandemic: Content Analysis and Review. JMIR Mhealth Uhealth. doi: 10.2196/19796

90. Collado-Borrell R, Escudero-Vilaplana V, Villanueva-Bueno C, Herranz-Alonso A and SanjurjoSaez M (2020) Features and functionalities of smartphone apps related to COVID-19. J Med Internet Res. doi: $10.2196 / 20334$

91. Shen C, Wang Z, Zhao F, Yang Y, Li J, Yuan J, Wang F, Li D, Yang M, Xing L, Wei J, Xiao H, Yang Y, Qu J, Qing L, Chen L, Xu Z, Peng L, Li Y, Zheng H, Chen F, Huang K, Jiang Y, Liu D, Zhang Z, Liu Y and Liu L (2020) Treatment of 5 Critically III Patients With COVID-19 With Convalescent Plasma. JAMA. doi: 10.1001/jama.2020.4783

92. Duan K, Liu B, Li C, Zhang H, Yu T, Qu J, Zhou M, Chen L, Meng S, Hu Y, Peng C, Yuan M, Huang J, Wang Z, Yu J, Gao X, Wang D, Yu X, Li L, Zhang J, Wu X, Li B, Xu Y, Chen W, Peng Y, Hu Y, Lin L, Liu X, Huang S, Zhou Z, Zhang L, Wang Y, Zhang Z, Deng K, Xia Z, Gong Q, Zhang W, Zheng X, Liu Y, Yang H, Zhou D, Yu D, Hou J, Shi Z, Chen S, Chen Z, Zhang X and Yang X (2020) Effectiveness of convalescent plasma therapy in severe COVID-19 patients. Proc Natl Acad Sci U S A 117:9490-9496. doi: 10.1073/pnas.2004168117

93. Ye M, Fu D, Ren Y, Wang F, Wang D, Zhang F, Xia X and Lv T (2020) Treatment with convalescent plasma for COVID-19 patients in Wuhan, China. J Med Virol. doi: 10.1002/jmv.25882

94. Perotti $C$, Baldanti F, Bruno R, Del Fante $C$, Seminari E, Casari S, Percivalle E, Glingani C, Musella V, Belliato M, Garuti M, Meloni F, Frigato M, Di Sabatino A, Klersy C, De Donno G, Franchini M and Covid-19 plasma task $f(2020)$ Mortality reduction in 46 severe Covid-19 patients treated with 
hyperimmune plasma. A proof of concept single arm multicenter trial. Haematologica. doi: 10.3324/haematol.2020.261784

95. Kuriya B, Cohen MD and Keystone E (2017) Baricitinib in rheumatoid arthritis: evidence-to-date and clinical potential. Ther Adv Musculoskelet Dis 9:37-44. doi: 10.1177/1759720X16687481

96. Furuta $\mathrm{Y}, \mathrm{Komeno} T$ and Nakamura $\mathrm{T}$ (2017) Favipiravir (T-705), a broad spectrum inhibitor of viral RNA polymerase. Proc Jpn Acad Ser B Phys Biol Sci 93:449-463. doi: 10.2183/pjab.93.027

97. Sheahan TP, Sims AC, Zhou S, Graham RL, Pruijssers AJ, Agostini ML, Leist SR, Schafer A, Dinnon KH, 3rd, Stevens LJ, Chappell JD, Lu X, Hughes TM, George AS, Hill CS, Montgomery SA, Brown AJ, Bluemling GR, Natchus MG, Saindane M, Kolykhalov AA, Painter G, Harcourt J, Tamin A, Thornburg NJ, Swanstrom R, Denison MR and Baric RS (2020) An orally bioavailable broad-spectrum antiviral inhibits SARS-CoV-2 in human airway epithelial cell cultures and multiple coronaviruses in mice. Sci Transl Med 12. doi: $10.1126 /$ scitranslmed.abb5883

98. de Oliveira JT, Santos AL, Gomes C, Barros R, Ribeiro C, Mendes N, de Matos AJ, Vasconcelos MH, Oliveira MJ, Reis CA and Gartner F (2015) Anti-influenza neuraminidase inhibitor oseltamivir phosphate induces canine mammary cancer cell aggressiveness. PLoS One 10:e0121590. doi: 10.1371/journal.pone.0121590

99. Eastman RT, Roth JS, Brimacombe KR, Simeonov A, Shen M, Patnaik S and Hall MD (2020) Remdesivir: A Review of Its Discovery and Development Leading to Emergency Use Authorization for Treatment of COVID-19. ACS Cent Sci 6:672-683. doi: 10.1021/acscentsci.0c00489

100. Emori T, Kasahara M, Sugahara S, Hashimoto M, Ito H, Narumiya S, Higashi Y and Fujii Y (2020) Role of JAK-STAT signaling in the pathogenic behavior of fibroblast-like synoviocytes in rheumatoid arthritis: Effect of the novel JAK inhibitor peficitinib. Eur J Pharmacol 882:173238. doi: 10.1016/j.ejphar.2020.173238

101. Guo X, Li W, Li Q, Chen Y, Zhao G, Peng Y and Zheng J (2019) Tofacitinib Is a Mechanism-Based Inactivator of Cytochrome P450 3A4. Chem Res Toxicol 32:1791-1800. doi: 10.1021/acs.chemrestox.9b00141

102. Elli EM, Barate C, Mendicino F, Palandri F and Palumbo GA (2019) Mechanisms Underlying the Anti-inflammatory and Immunosuppressive Activity of Ruxolitinib. Front Oncol 9:1186. doi: 10.3389/fonc. 2019.01186

103. Oscanoa TJ, Romero-Ortuno R, Carvajal A and Savarino A (2020) A pharmacological perspective of Chloroquine in SARS-CoV-2 infection. Int J Antimicrob Agents:106078. doi: 10.1016/j.ijantimicag.2020.106078

104. Graves PR, Kwiek JJ, Fadden P, Ray R, Hardeman K, Coley AM, Foley M and Haystead TA (2002) Discovery of novel targets of quinoline drugs in the human purine binding proteome. Mol Pharmacol 62:1364-72. doi: 10.1124/mol.62.6.1364

105. O'Hanlon R, Leyva-Grado VH, Sourisseau M, Evans MJ and Shaw ML (2019) An Influenza Virus Entry Inhibitor Targets Class II PI3 Kinase and Synergizes with Oseltamivir. ACS Infect Dis 5:1779-1793. doi: 10.1021/acsinfecdis.9b00230

106. Ono H (2019) [Hypothermic Action of Oseltamivir Not Dependent on Its Anti-influenza Virus Action]. Yakugaku Zasshi 139:767-781. doi: 10.1248/yakushi.18-00191

107. De Clercq E (2002) New developments in anti-HIV chemotherapy. Biochim Biophys Acta 1587:258-75. doi: 10.1016/s0925-4439(02)00089-3

108. Paskas S, Mazzon E, Basile MS, Cavalli E, Al-Abed Y, He M, Rakocevic S, Nicoletti F, Mijatovic S and Maksimovic-Ivanic D (2019) Lopinavir-NO, a nitric oxide-releasing HIV protease inhibitor, suppresses the growth of melanoma cells in vitro and in vivo. Invest New Drugs 37:1014-1028. doi: 10.1007/s10637019-00733-3

109. Mesa RA (2010) Ruxolitinib, a selective JAK1 and JAK2 inhibitor for the treatment of myeloproliferative neoplasms and psoriasis. IDrugs 13:394-403. 
110. Fu C, Sikandar A, Donner J, Zaburannyi N, Herrmann J, Reck M, Wagner-Dobler I, Koehnke J and Muller R (2017) The natural product carolacton inhibits folate-dependent C1 metabolism by targeting FolD/MTHFD. Nat Commun 8:1529. doi: 10.1038/s41467-017-01671-5

111. Chen IS and Kubo Y (2018) Ivermectin and its target molecules: shared and unique modulation mechanisms of ion channels and receptors by ivermectin. J Physiol 596:1833-1845. doi: $10.1113 / J P 275236$

112. Li D, Zhang Y, Zhao RN, Fan S and Han JG (2014) Investigation on the mechanism for the binding and drug resistance of wild type and mutations of G86 residue in HIV-1 protease complexed with Darunavir by molecular dynamic simulation and free energy calculation. J Mol Model 20:2122. doi: 10.1007/s00894-014-2122-y

113. McEvoy GK (2003) AHFS Drug information 2003. Bethesda, Md. : American Society of HealthSystem Pharmacists, (C2003.

114. Kumar V, Dhanjal JK, Bhargava P, Kaul A, Wang J, Zhang H, Kaul SC, Wadhwa R and Sundar D (2020) Withanone and Withaferin-A are predicted to interact with transmembrane protease serine 2 (TMPRSS2) and block entry of SARS-CoV-2 into cells. J Biomol Struct Dyn:1-13. doi: 10.1080/07391102.2020.1775704

115. Pardanani A, Harrison C, Cortes JE, Cervantes F, Mesa RA, Milligan D, Masszi T, Mishchenko E, Jourdan E, Vannucchi AM, Drummond MW, Jurgutis M, Kuliczkowski K, Gheorghita E, Passamonti F, Neumann F, Patki A, Gao G and Tefferi A (2015) Safety and Efficacy of Fedratinib in Patients With Primary or Secondary Myelofibrosis: A Randomized Clinical Trial. JAMA Oncol 1:643-51. doi: 10.1001/jamaoncol.2015.1590 


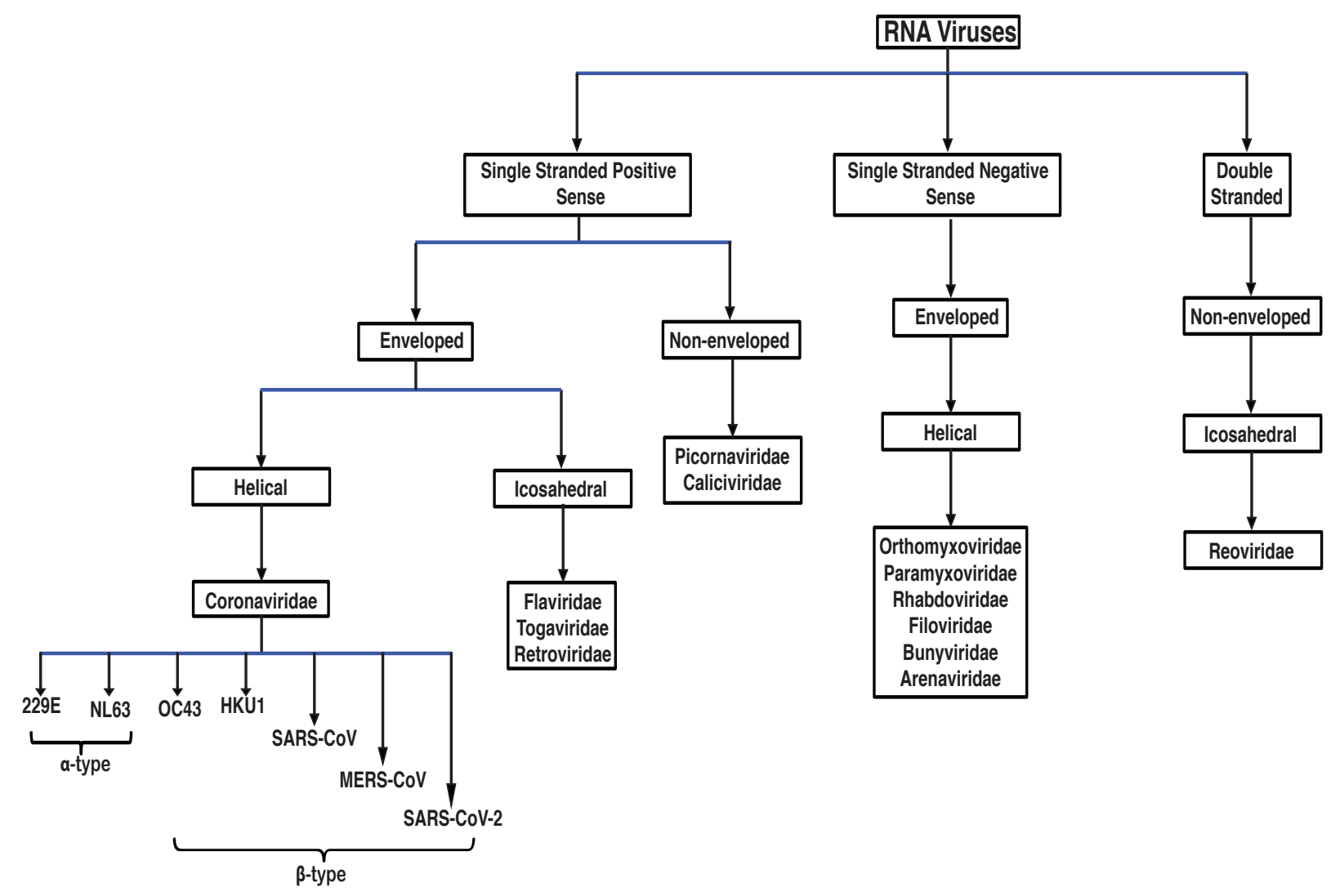

Figure-1. Classification of RNA-based viruses and flow-chart showing the belongingness of Coronavirus and other closely related RNA viruses

This schematic classification of the Coronaviridae family shows how the members are divided based on sense and anti-sense strands. SARS-CoV-2 falls in category of single stranded sense strand RNA virus that is enveloped and possesses helical capsid. The $\alpha$-coronaviruses are: $229 \mathrm{E}$ and NL63. Except SARS-CoV-2, there are other member of the $\beta$-coronavirus types are: OC43, HKU1, SARS-CoV, and MERS-CoV. 


\section{FIGURE-1.}

A.

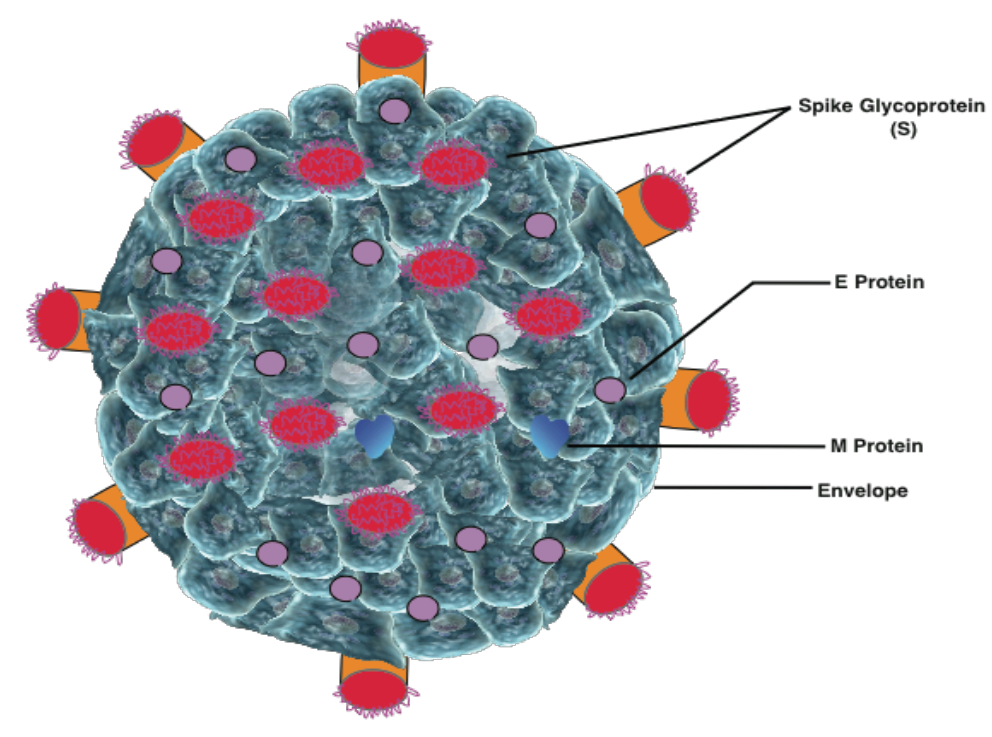

B.

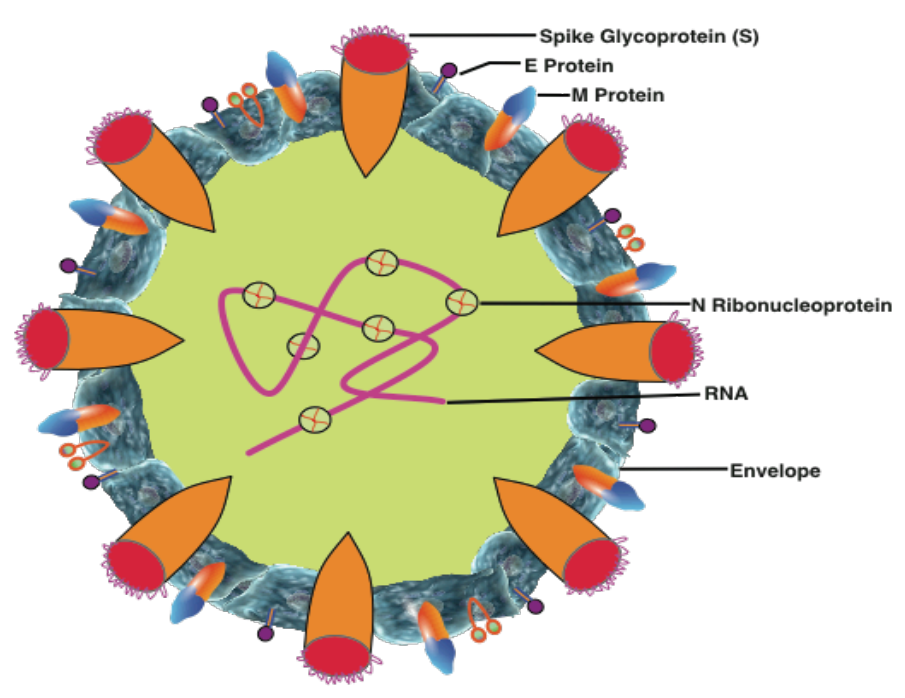

Figure-2. Structure of the SARS-CoV-2 virus

SARS-CoV-2 is a RNA virus that contains envelope (E), membrane (M), spike (S), and nucleocapsid (N) proteins. The RNA is single positive-sense strand. Among those, M, S and E are glycoproteins in nature. The viral nucleo-capsid is made of proteinaceous coat capsid, inside which RNA and non-histone protein reside. SARS-CoV-2 also contains shorter spikes that possess hemagglutininesterase (HE) protein; their size is larger in case of Toroviruses. 


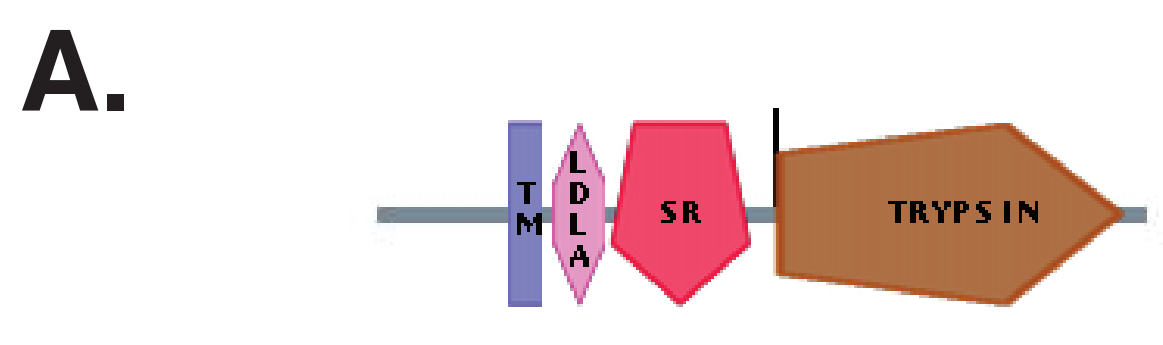

B.

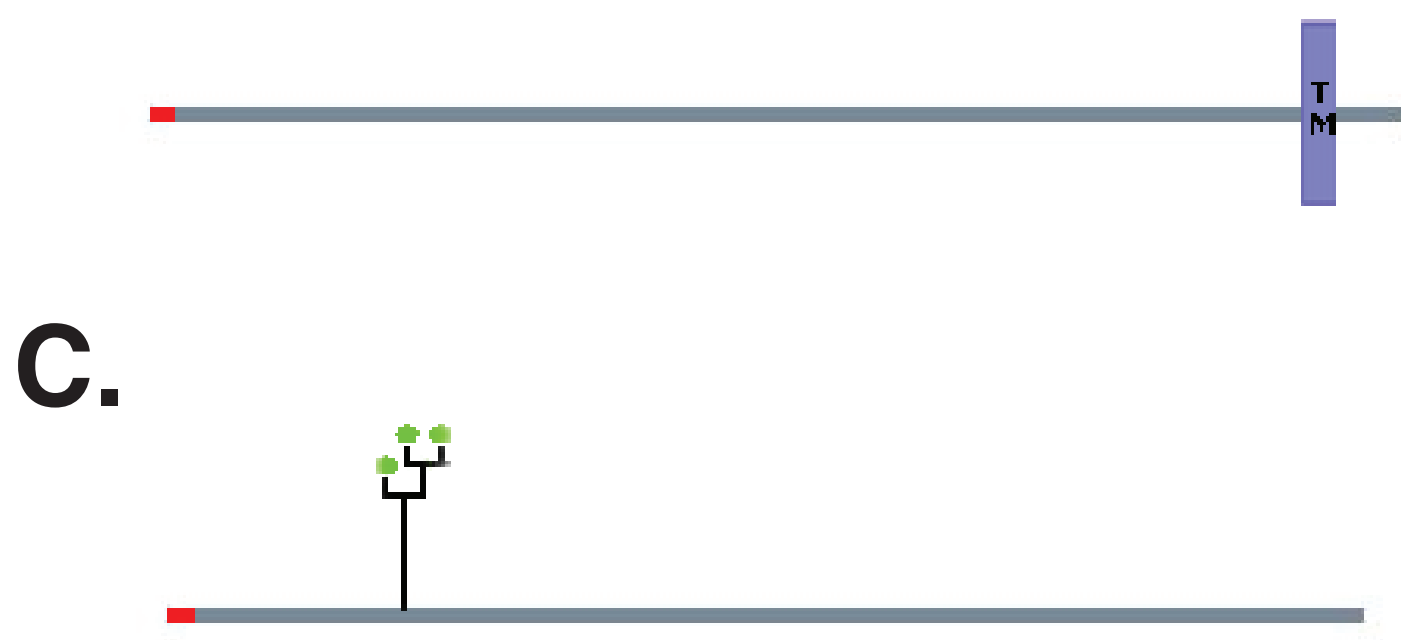

Figure-3: Protein Architecture of Protein Architecture of ACE2, TMPRSS2, and DPP4: (A) TMPRSS2 is a protease which consists of four domains LDLA, SR, TRYPSIN, and TM domain (B) ACE2, an enzyme possess one TM domain and one signal peptide, (C) DPP4 is a protease which contains one signal peptide. The increased expression of ACE2 and TMPRSS2 in the upper respiratory tract compared with blood and lower respiratory tract could contribute to the increased replication of SARS-CoV-2 in this tissue. 


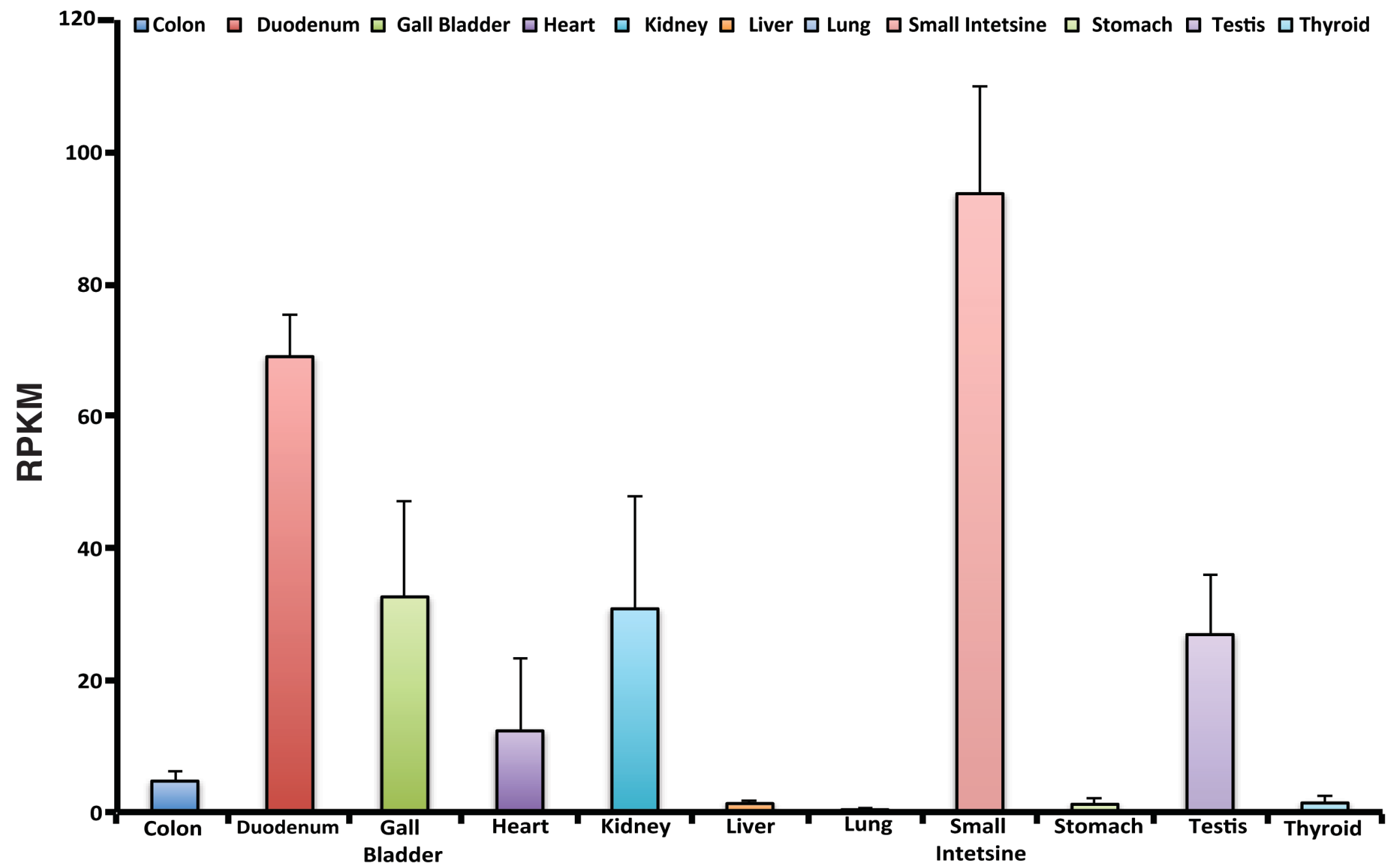

Figure-4. ACE2 Expression across major normal human organs

The RNAseq derived data shows expression of ACE2 transcript across different organs including colon, duodenum, gall bladder, heart, kidney, liver, lung, small intestine, stomach, testis and thyroid. The value of expression is shown in form of Reads Per Kilobase of transcript, per million mapped reads (RPKM), which is a normalized unit for denoting transcript expression. 


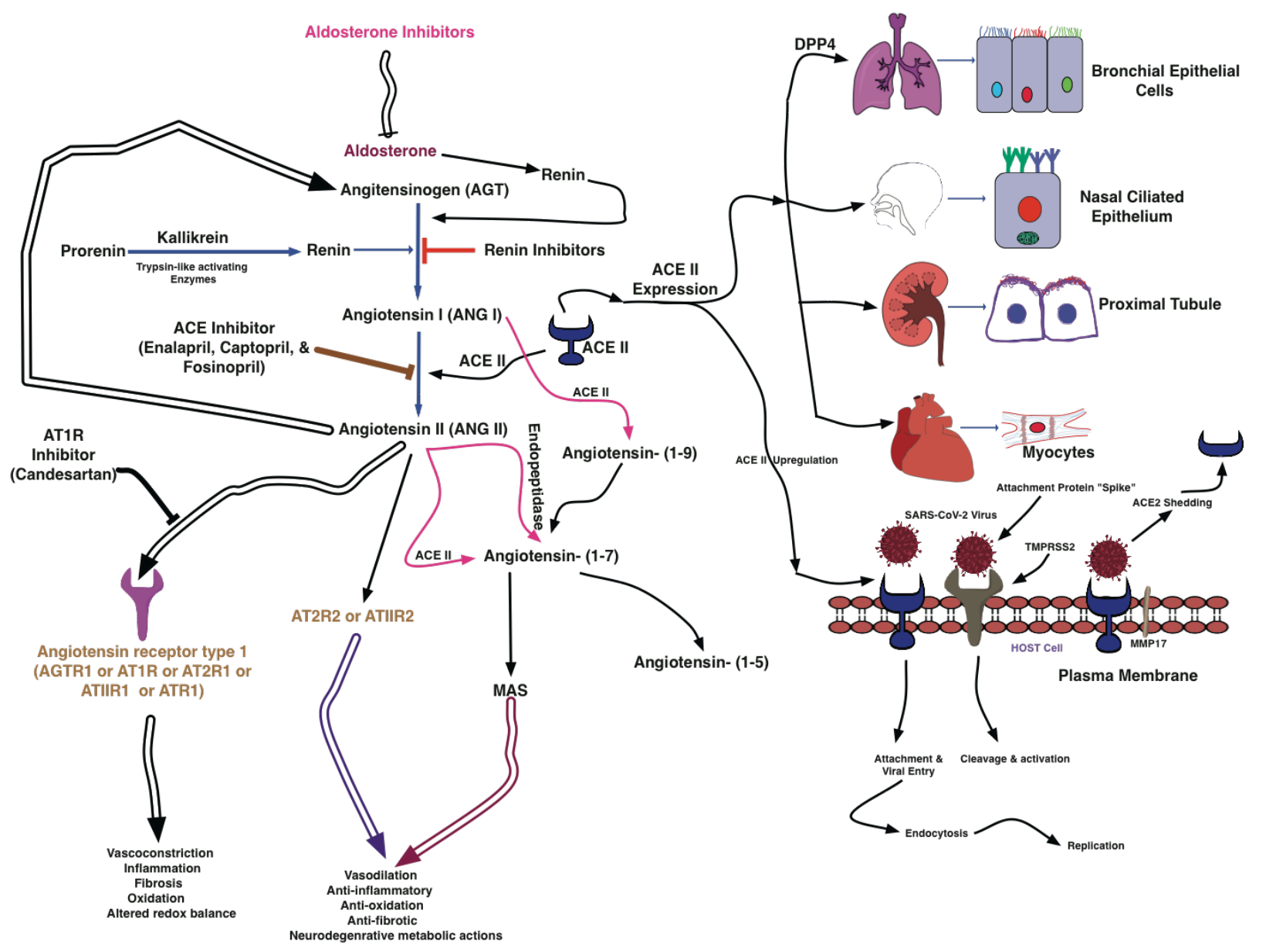

Figure-5: Major sites of ACE2 expression, Binding of SARS-CoV-2 to ACE2 receptor, and involvement of TMPRSS2, and DPP4 in SARS-CoV-2 entry:

The spike protein (S) helps SARS-CoV-2 to enter into the host cell via binding to its receptor Angiotensin Converting Enzyme 2 (ACE2) that is part of the renin-angiotensin-aldosterone system (RAAS). RAAS and its component include angiotensinogen (AGT), the enzyme renin, angiotensin converting enzyme (ACE), and their hydrolytic products angiotensins I \& II. Once SARS-CoV-2 binds to ACE2, it internalize through the process of endocytosis into the cells, which leads to downregulation of membrane-anchored ACE2. A decrease in ACE2 levels led to organ damage via activation and deactivation of ACE/Ang II/AT1R \& ACE2/Ang- (1-7)/Mas-R pathways, respectively. There is alternate route of infection of SARS-CoV-2 is via 
transmembrane protease serine 2 (TMPRSS2) driven cleavage of SARS-CoV-2 escorted through ACE2. Due to this membrane shedding of ACE2 occurs by disintegrin and MMP17. Furthermore, soluble form of ACE2 obstructs SARS-CoV-2 from binding to membraneanchored ACE2 in plasma membrane. An increased amount of soluble ACE2 and expression induced due to RAS inhibitors could be advantageous for protecting lungs and other organ injury but not infection with SARS-CoV-2. 


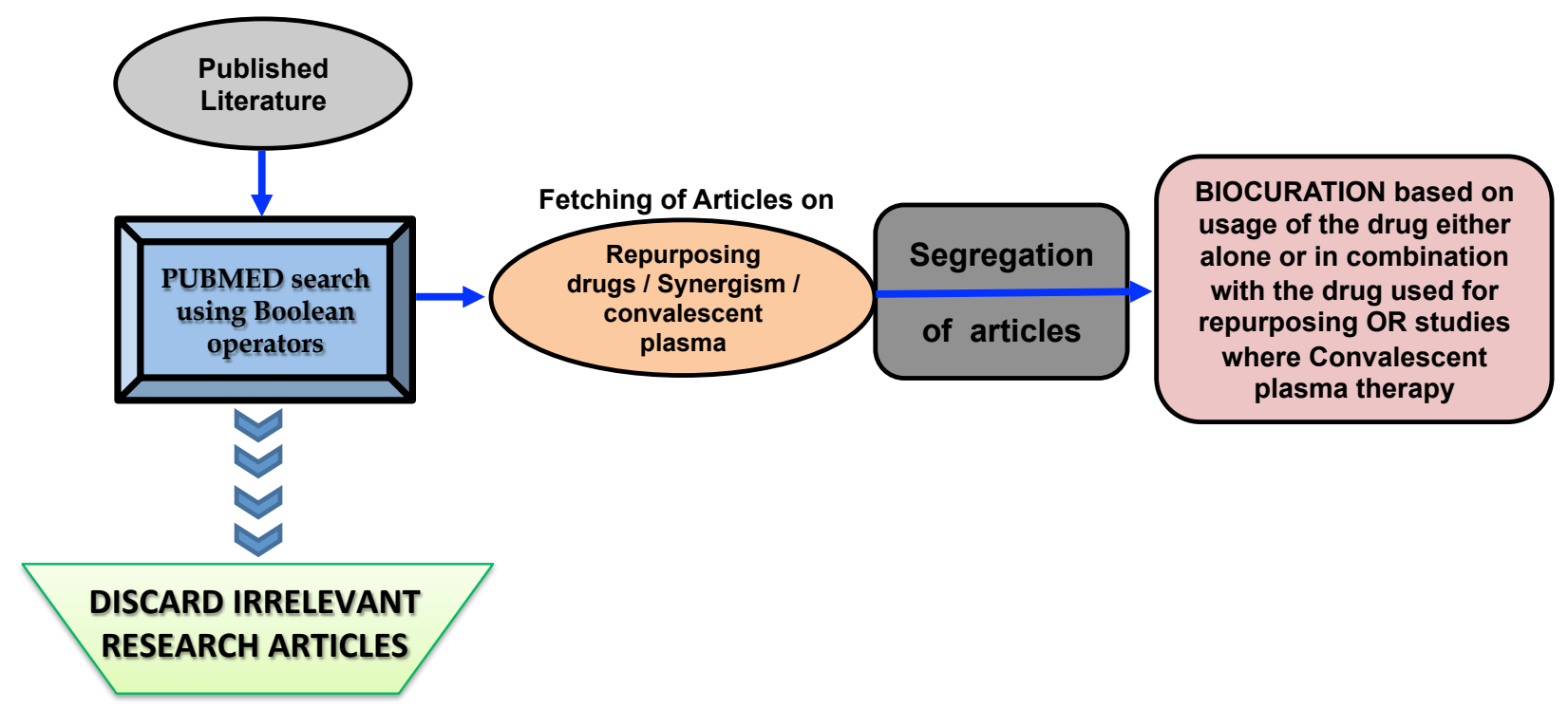

Figure-6: Schema for the screening of the articles reporting drugs repurposed for COVID-

19: The NCBI search engine was searched using Boolean operators such as AND, NOT, \& OR. The articles were fetched for repurposing drugs, synergism or convalescent plasma in combination with COVID-19. The articles were further segregated based on the agent used for drug repurposing. 


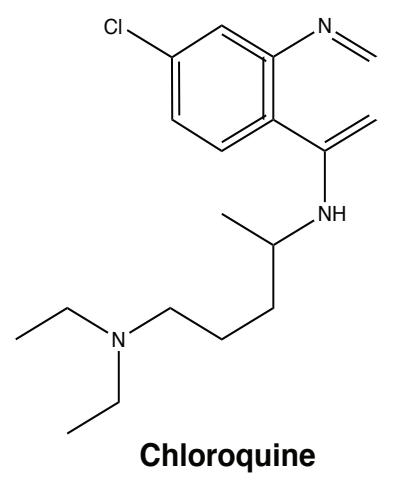

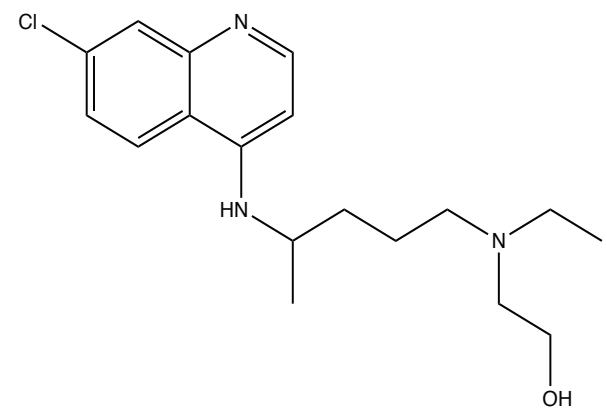

Hydroxychloroquine

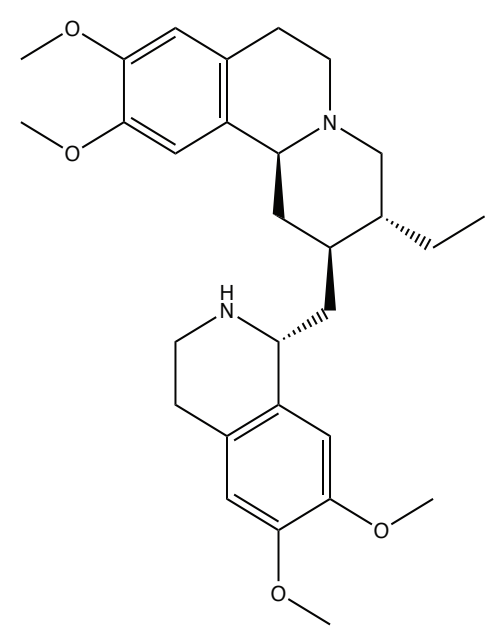

Emetine

Figure-7: Structure of Anti-malarial/parasitic drugs: Chloroquine, hydroxychloroquine, and emetine are the drugs which have been extensively in use for the treatment of COVID-19 patients. 


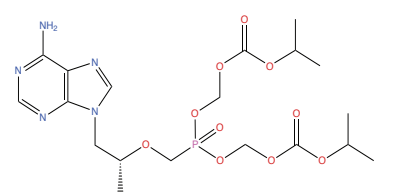

Tenofovir disoproxil

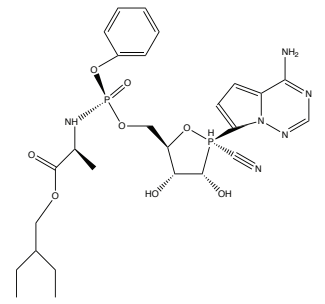

Remdesivir

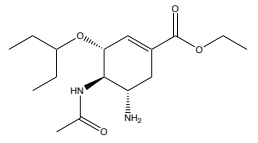

Oseltamivir

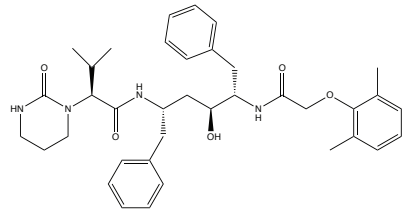

Lopinavir

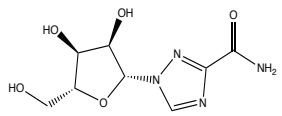

Ribavirin

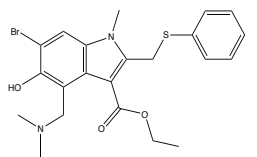

Arbidol

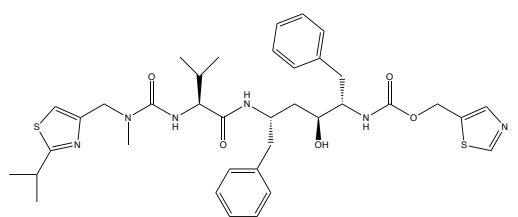

Ritonavir

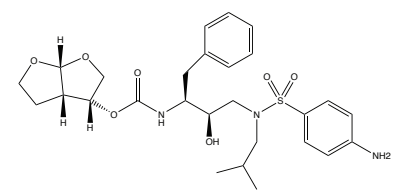

Darunavir

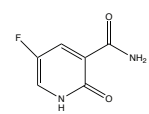

Favipiravir

Figure-8: Structure of anti-viral or antiretroviral repurposing drugs used for treatment of COVID-19: A number of drugs that have been approved by the FDA for use in viral diseases particularly retroviruses are repurposed to treat COVID-19 patients. Some of those are Tenofovir, Lopinavir, Ritonavir, Remdesivir, Ribavirin, Darunavir, Oseltamivir, Arbidol, and Favipiravir. 


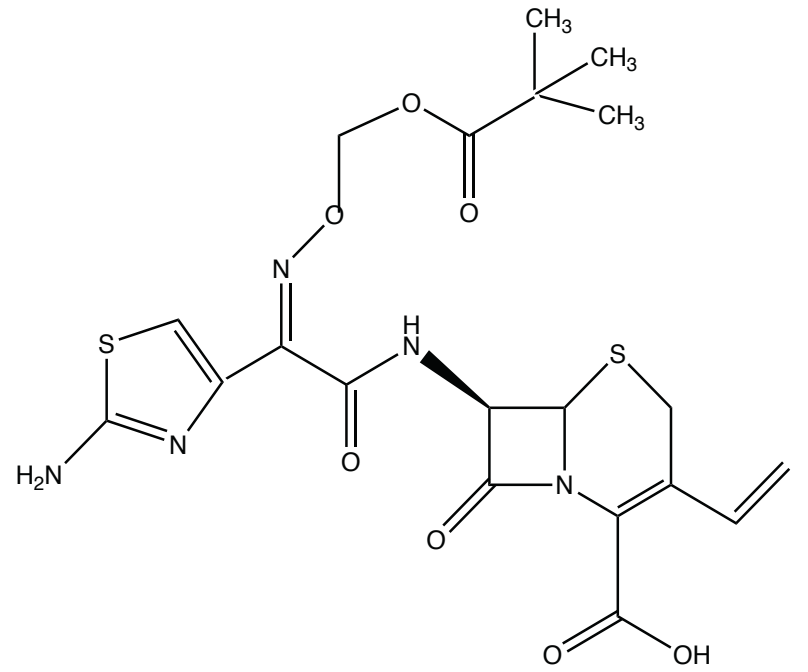

Anakinra

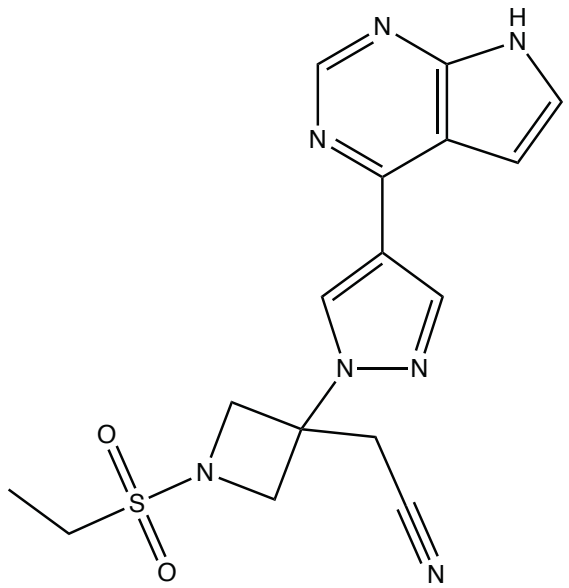

Barcitinib

Figure-9: Anti-rheumatic drugs used for treatment of COVID-19: A number of repurposed drugs for against COVID-19 are those used extensively for Rheumatoid arthritis such as Anakinra, and Barcitinib. 
Table-1: List of Mitigation Strategies in form of Do's and Don'ts to stop transmission of SARS-CoV-2

\begin{tabular}{|c|c|c|c|c|c|}
\hline S. No. & Parameter & Don'ts & Do's & Mechanism & Reference \\
\hline 1. & Smoking & $\mathcal{V}$ & & $\begin{array}{l}\text { Smokers have increased expression of ACE2 receptor } \\
\text { in SARS-CoV-2 virus infected cells }\end{array}$ & Brake et al 2020[76] \\
\hline 2. & $\begin{array}{l}\text { PPE (medical } \\
\text { professional) }\end{array}$ & & $\mathcal{V}$ & $\begin{array}{l}\text { Personal protection equipment kit is very essential for } \\
\text { health care personnel to wear specially those dealing } \\
\text { with nCoV-19 patients/suspects. }\end{array}$ & $\begin{array}{l}\text { Giwa et al 2020[77] } \\
\text { https://www.who.int/emergencies/diseases/n } \\
\text { ovel-coronavirus-2019/technical- } \\
\text { guidance/infection-prevention-and-control }\end{array}$ \\
\hline 3. & Mask & & $\mathcal{V}$ & $\begin{array}{l}\text { SARS-CoV-2 spreads through droplets or aerosol so a } \\
\text { proper mask is required to spread transmission of SARS- } \\
\text { CoV-2 from asymptomatic, pre-symptomatic, and mildly } \\
\text { symptomatic individuals. N95 masks have penetration } \\
\text { size from 0.1-0.3 micron. }\end{array}$ & $\begin{array}{l}\text { Tirupathi et al } 2020[78] \\
\text { https://www.who.int/emergencies/diseases/n } \\
\text { ovel-coronavirus-2019/technical- } \\
\text { guidance/infection-prevention-and-control }\end{array}$ \\
\hline 4. & Hand Sanitization & & $\mathcal{V}$ & $\begin{array}{l}\text { The cleaning and washing hands with alcohol or with } \\
\text { soap and water must be done or } 20-30 \text { seconds. } \\
\text { Methanol, isopropyl alcohol and ethanol are major } \\
\text { disinfectant agents. Ethanol concentrations of } 60-95 \% \\
\text { (v/v) are safe and effective for disinfection. }\end{array}$ & $\begin{array}{l}\text { Berardi et al } 2020[79] \\
\text { https://www.who.int/emergencies/diseases/n } \\
\underline{\text { ovel-coronavirus-2019/advice-for-public }}\end{array}$ \\
\hline 5 & $\begin{array}{l}\text { Social / Physical } \\
\text { distancing }\end{array}$ & & $\nu$ & $\begin{array}{l}\text { Maintain a social distance of at least } 2 \text { meter or } \sim 6 \text { feet is } \\
\text { required to avoid infection. }\end{array}$ & Maclntyre et al 2020[80] \\
\hline 6 & $\begin{array}{l}\text { Visit of Crowded } \\
\text { places }\end{array}$ & $\nu$ & & $\begin{array}{l}\text { Gathering is a good source to spread or getting infection } \\
\text { with SARS-CoV-2 virus because at crowded places it is } \\
\text { hard to maintain a social or physical distance of } 2 \text { meter } \\
\text { ( } 6 \text { feet). Social distancing is crucial in preventing } \\
\text { community transmission. }\end{array}$ & Wilder-Smith et al 2020[81] \\
\hline 7. & $\begin{array}{l}\text { Touching eyes, } \\
\text { nose, and mouth }\end{array}$ & $\mathcal{V}$ & & $\begin{array}{l}\text { The virus transmission can be through infected person's } \\
\text { airways/droplets (Aerosol), nose or mouth to recipient's } \\
\text { eyes, mouth or nosed. Touching surface with bare hands } \\
\text { can caught up the virus. }\end{array}$ & West et al 2020[82] \\
\hline 8 & $\begin{array}{l}\text { Updating of } \\
\text { information }\end{array}$ & & $\nu$ & $\begin{array}{l}\text { It is of utmost importance to keep up to date on the latest } \\
\text { information from trusted sources, such as WHO or your } \\
\text { local and national health authorities The international and } \\
\text { national agencies provides the most updated information }\end{array}$ & Santos et al 2017[83] \\
\hline
\end{tabular}


Alcoholic

Sanitizers to be out of reach

Sharing of cup, utensils, food, or drink items
12

14. on norms or advise people need to follow in the area they are residing during the pandemic.

$\checkmark$ It is poisonous and should be kept out of the reach of children as they have more probability of accidental swallowing and ingestion. Reported health effects after swallowing are drowsiness, eye irritation, nausea, vomiting, etc. Methanol is very toxic and may prove life threatening sometimes. Alcohol vapor is also harmful.

It transmits infection

https://www.who.int/docs/defaultsource/coronaviruse/key-messages-andactions-for-covid-19-prevention-and-controlin-schools-march-2020.pdf?sfvrsn=baf81d52_4

Müller et al 2020[84]

Adhikari et al 2020[85], are; rules on distance and hygiene to prohibitions on meetings and extension of school and university holidays to the closure of all non-system-relevant facilities in a country in connection with the regulation of individual freedom of movement i.e. lockdown.

\section{Face Masks}

Namaste

Handshake, fist bump, high five and hugs

COVID-19

associated app provided by the

government

Make a note of

helpline number

of Emergency

Medical Facility
Facemasks prevent spreading of droplets coming in coughs and sneezing

$\checkmark$ This way of greeting avoids physical touch as observed in hand shaking.

If individuals will go for these types of greetings or mode of celebration, transmission of virus will happen.

It's always good to upload COVID-19 app on your mobile to know latest update as well as COVID-19 positive patient in the vicinity

$\checkmark \quad$ In case if you have fever, difficulty in breathing and cough
Ozma et al 2020[86]

Kulkarni et al 2020 [87]

Pascarella et al 2020[88]

Adhikari et al 2020 [85]

Ming et al 2020[89]

Collado-Borrell et al 2020[90], https://www.mohfw.gov.in/pdf/Poster_Co rona_ad_Eng.pdf 
Table-2. Titer ratio among different studies where Convalescent plasma has been used as a treatment option for COVID-19 patients

\begin{tabular}{|c|c|c|c|c|}
\hline Region/Country & Titer & $\begin{array}{l}\text { Sample } \\
\text { Size }\end{array}$ & Patient Outcome & References \\
\hline $\begin{array}{l}\text { Dongguan, Xiangtan, } \\
\text { Xiaolan cities of China }\end{array}$ & $>1: 320$ & 06 & $\begin{array}{c}\text { The patients treated with CP did not require } \\
\text { mechanical ventilation and } 11 \text { days post-CP treatment } \\
\text { were transferred to a general ward. }\end{array}$ & Zhang et al 2020 [28] \\
\hline Shenzhen, China & $\begin{array}{l}\text { ELISA anti-SARS-CoV-2 AB } \\
>1: 1000, \text { and neutralization } \\
\text { titer }>40\end{array}$ & 05 & $\begin{array}{c}\text { SARS-CoV-2-specific antibody titers ranged between } \\
1: 800-16: 200, \text { NAbs titers from } 80-480 \text {, reduced the } \\
\text { viral load, }\end{array}$ & Shen et al 2020[91] \\
\hline Wuhan, China & $\begin{array}{l}\text { Neutralizing Anti-SARS- } \\
\text { CoV-2 } A B>\sim 1: 640\end{array}$ & 40 & Reduced the viral load & Duan et al 2020 [92] \\
\hline Wuhan, China & Not mentioned & 06 & $\begin{array}{l}\text { Serologic analysis indicated an immediate increase in } \\
\text { anti-SARS-CoV-2 antibody titers in patients \#2 and } \\
\text { \#3, but not in-patient \#1. }\end{array}$ & Ye et al 2020[93] \\
\hline South Korea & Not mentioned & 02 & $\begin{array}{l}\text { Two COVID-19 patients were treated using } \\
\text { convalescent plasma therapy. Both showed a } \\
\text { favorable outcome }\end{array}$ & Ahn et al 2020[30] \\
\hline Italy & $\geq 1: 160$ & 46 & $\begin{array}{c}\text { Primary outcome was } 7 \text {-days hospital mortality and } \\
6.5 \% \text { patients died within } 7 \text { days }\end{array}$ & Perrotti et al 2020[94] \\
\hline
\end{tabular}


Table-3: The drugs repurposed to treat COVID-19, their mode, molecule targeted and possible mechanism of action (wherever applicable)

\begin{tabular}{|c|c|c|c|c|}
\hline $\begin{array}{l}\text { Name of the agent } \\
\text { (Mode of giving to the } \\
\text { patients) }\end{array}$ & Type & $\begin{array}{l}\text { Originally Used for } \\
\text { the diseases }\end{array}$ & Target & Reference \\
\hline Baricitinib (Oral) & Active ingredient of Olumiant & Rheumatoid arthritis & Reversible JAK inhibitor & Kuriyaet al 2017[95] \\
\hline $\begin{array}{l}\text { Favipiravir (An oral anti-viral } \\
\text { drug) }\end{array}$ & Analogue of purine origin & Influenza & $\begin{array}{l}\text { RdRp catalytic site } \\
\text { preventing virus replication }\end{array}$ & Furata et al 2017[96] \\
\hline $\begin{array}{l}\text { EIDD-2801 (An oral anti-viral } \\
\text { drug) }\end{array}$ & Ribonucleotide analog & Not Yet & Same enzyme as remdesivir & Sheahan et al 2020[97] \\
\hline $\begin{array}{l}\text { Oseltamivir (orally } \\
\text { administered drug) }\end{array}$ & Sialic acid analogue & Influenza $A$ and $B$ & Neuraminidase & Oliveira et al 2015[98] \\
\hline $\begin{array}{l}\text { Remdesivir } \\
\text { (Intravenously) }\end{array}$ & An adenosine analogue & Flu virus (influenza) & Viral RNA polymerase & Eastman et al 2020[99] \\
\hline Tofacitinib (Oral) & An-acylpiperidines & $\begin{array}{l}\text { Psoriatic arthritis and } \\
\text { rheumatoid arthritis }\end{array}$ & $\begin{array}{l}\text { Selective JAK1 \& JAK3 } \\
\text { inhibitor, inhibits CYP3A4 }\end{array}$ & $\begin{array}{l}\text { Emori et al 2020[100], } \\
\text { Guo et al 2019[101] }\end{array}$ \\
\hline Ruxolitinib (Oral) & Apyrrolo [2,3-d]pyrimidines & High-risk myelofibrosis & Inhibitor of JAK1 \& JAK2 & Elli et al 2019[102] \\
\hline Chloroquine & $\begin{array}{l}\text { Anaminoquinolone } \\
\text { derivative }\end{array}$ & $\begin{array}{c}\text { Malaria, HIV, Q } \\
\text { fever, Whipple's } \\
\text { disease }\end{array}$ & $\begin{array}{l}\text { Inhibits caspase-1 } \\
\text { (CASP1), NLRP3 }\end{array}$ & $\begin{array}{l}\text { Oscanoa et al 2020[103] } \\
\text { Plantone et al } 2018\end{array}$ \\
\hline
\end{tabular}




\begin{tabular}{|c|c|c|c|c|}
\hline $\begin{array}{l}\text { Hydroxychloroquine } \\
\text { (Oral) }\end{array}$ & 4-Aminoquinoline & $\begin{array}{l}\text { Malaria, Rheumatoid } \\
\text { arthritis and Lupus }\end{array}$ & ALDH1 and QR2 & Graves et al 2002[104] \\
\hline $\begin{array}{l}\text { Oseltamivir } \\
\quad \text { (Oral) }\end{array}$ & $\begin{array}{l}\text { Antiviral neuraminidase } \\
\text { inhibitor }\end{array}$ & Influenza A \& B & $\begin{array}{l}\text { Neuraminidases, lon } \\
\text { channels of nicotinic } \\
\text { acetylcholine receptors }\end{array}$ & $\begin{array}{l}\text { O'Hanlon et al 2019[105 } \\
\text { Ono et al 2019[106] }\end{array}$ \\
\hline $\begin{array}{l}\text { Lopinavir } \\
\text { (Oral) }\end{array}$ & $\begin{array}{c}\text { Antiretroviral protease } \\
\text { inhibitor }\end{array}$ & HIV & Mimetic Protease & $\begin{array}{l}\text { De Clercq 2002[107], } \\
\text { Paskas et al 2019[108] }\end{array}$ \\
\hline Ruxolitinib (Oral) & Cancer growth blocker & Myelofibrosis & $\begin{array}{l}\text { Janus Kinase inhibitor (JAK } \\
\text { inhibitor) with selectivity for } \\
\text { subtypes JAK1 and JAK2 }\end{array}$ & Mesa 2010 [109] \\
\hline Carolacton & $\begin{array}{c}\text { Macrolide keto-carboxilic } \\
\text { acid (A natural product } \\
\text { Bio-film inhibitor } \\
\text { Isolated from } \\
\text { Sorangiumcellulosum) }\end{array}$ & Antibacterial & FolD/MTHFD & Fu et al 2017[110] \\
\hline $\begin{array}{l}\text { Darunavir } \\
\text { (Oral) }\end{array}$ & $\begin{array}{l}\text { Anti-retroviral protease } \\
\text { inhibitor }\end{array}$ & $\begin{array}{l}\text { Binds to the active } \\
\text { site of HIV-1 } \\
\text { protease, and inhibits } \\
\text { the dimerization and } \\
\text { catalytic activity of } \\
\text { HIV-1 protease }\end{array}$ & $\begin{array}{c}\text { Target wild-type HIV-1 } \\
\text { protease }\end{array}$ & Li et al 2014[112] \\
\hline
\end{tabular}


Ritonavir

(Oral)

CamostatMesylate (Oral)

Fedratinib (Oral)

Anakinra (Subcutaneous)
An antiretroviral protease inhibitor

HIV

Potent serine protease inhibitor

JAK2-selective kinase inhibitor

Antagonist of IL1R
Pancreatitis, and esophagitis

Mylofibrosis

Rheumatoid arthritis
HIV replication cycle after translation and before

assembly

TMPRSS2

JAK2

IL1R
McEvoy et al 2003[113]

Kumar et al 2020[114]

Pardanani et al 2015[115]

Huet et al 20202[55] 